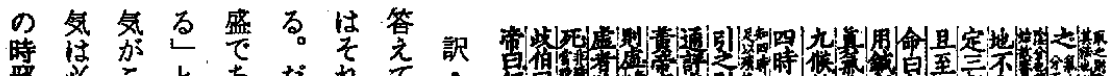

邪必こと古だれで

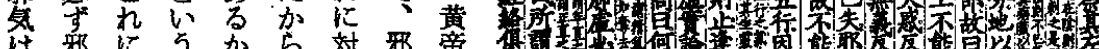

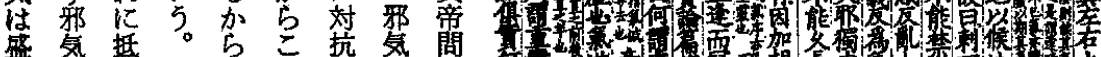

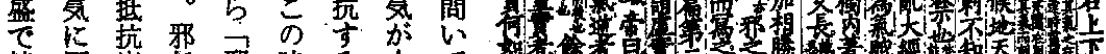

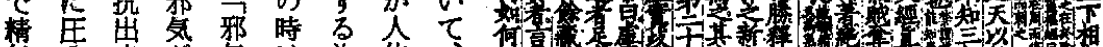

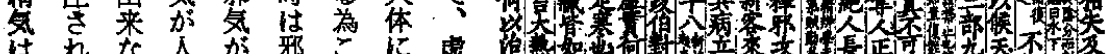

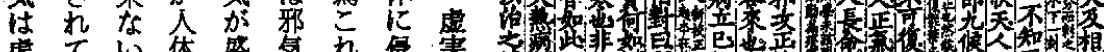

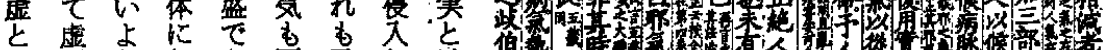

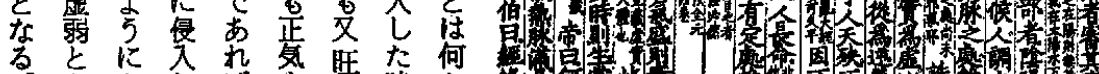

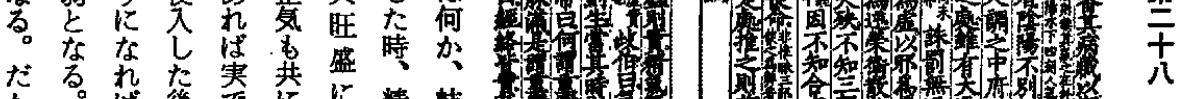

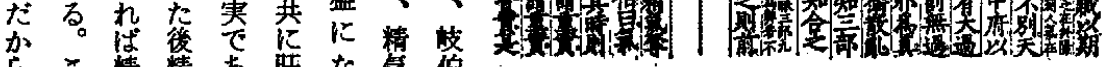

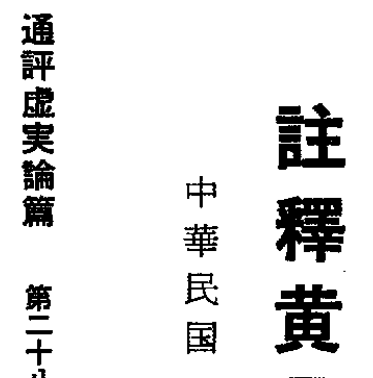

らこ精精あ旺な炎伯

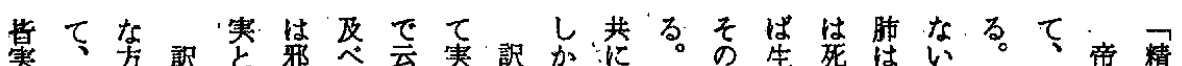

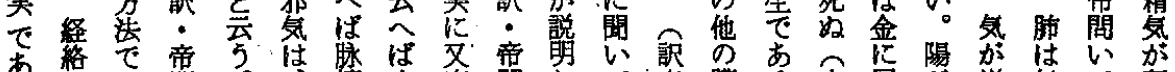

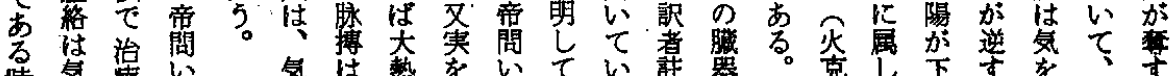
時気䄓

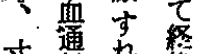
吉行㷊笶

の道よ, 共

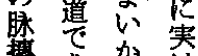

搏古加学

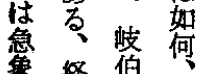

落答

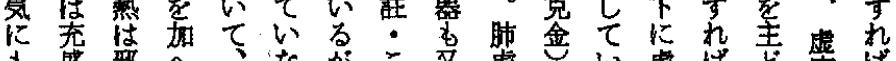

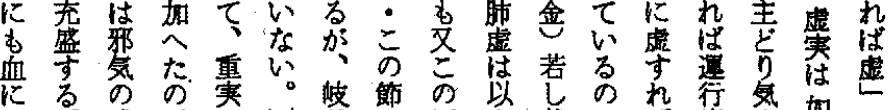

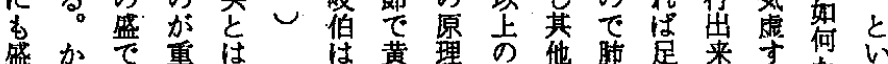

校镬

$\overline{71}$

森

론

て 㷫寒何

あら勢で吕

加全全伯

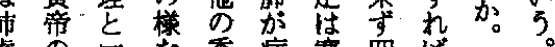

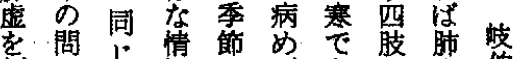

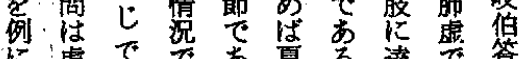

者

뵤묘

\title{
当 髅
}

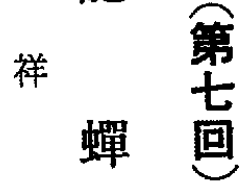

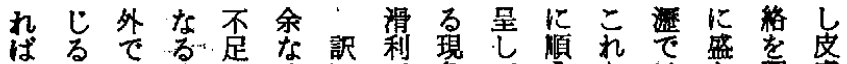

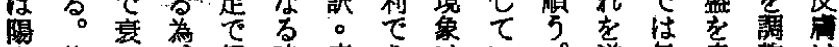
虚絡会経時帝あは心。逆意整性

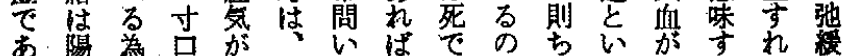

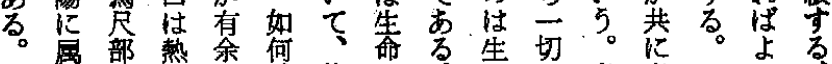

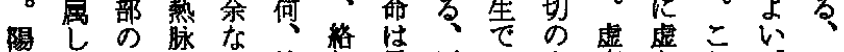

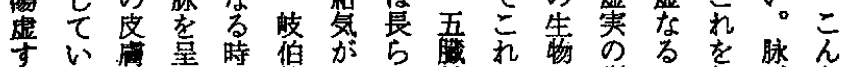

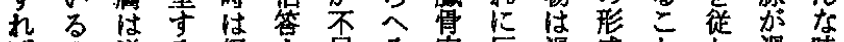

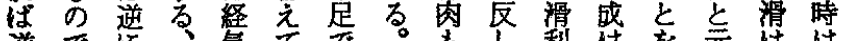

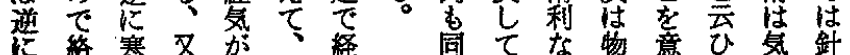

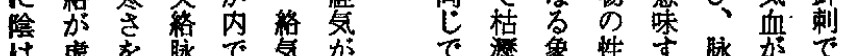

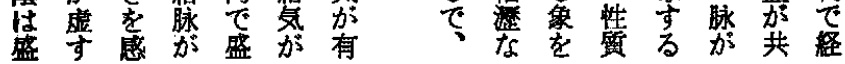

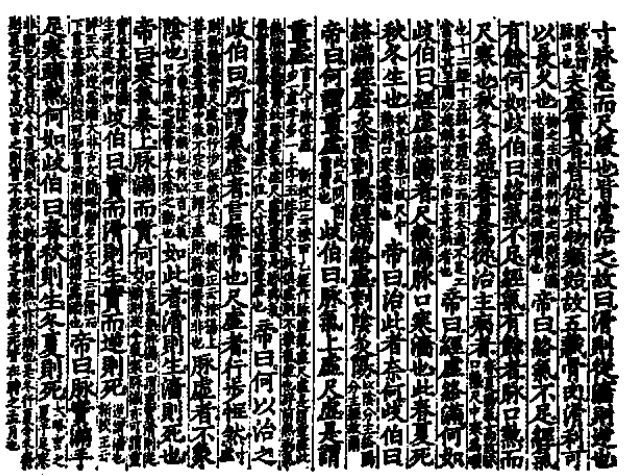

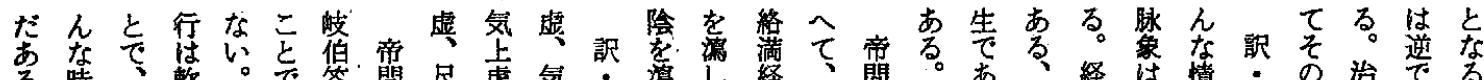

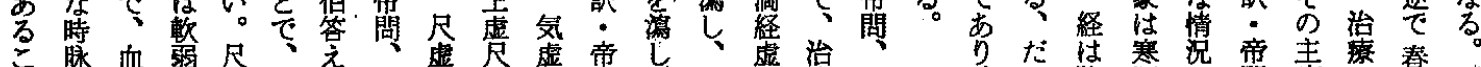

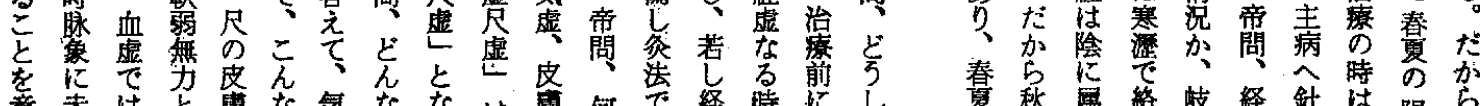

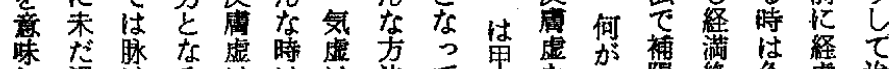

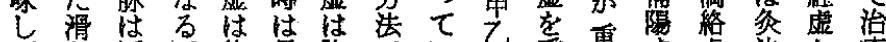

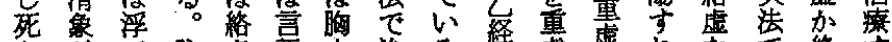

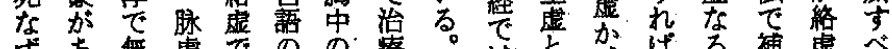

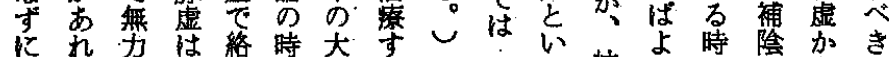

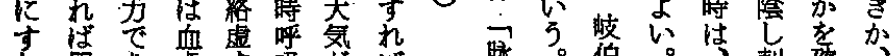

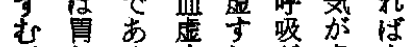

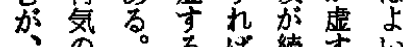
眿末こ气步妿るか

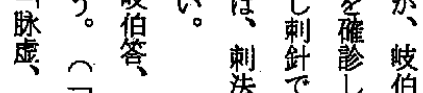

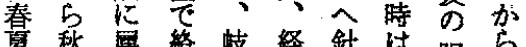

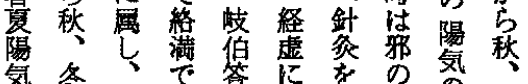

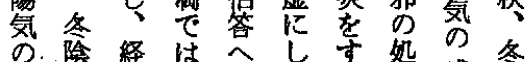

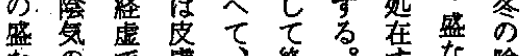

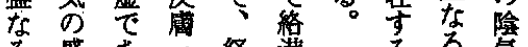

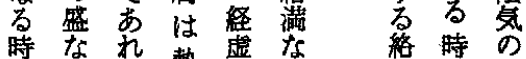

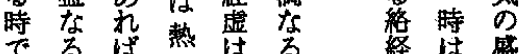
は時陰感寸時往な

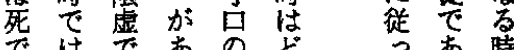


脉腠陽 う 陰熱るる節状が上下脉涼ばてでしす 推る問死象

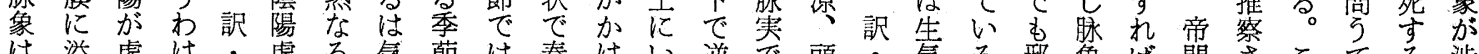

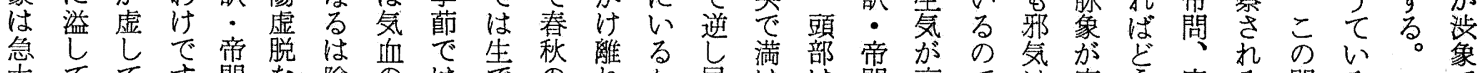

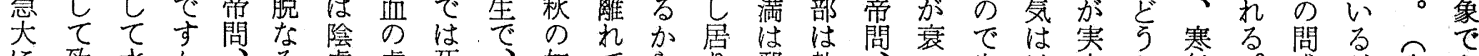

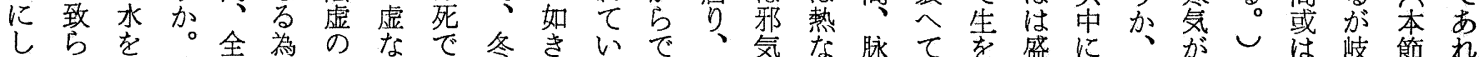

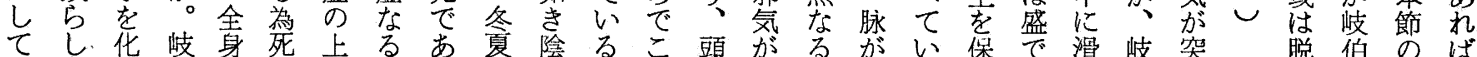

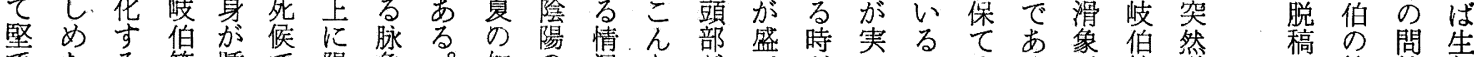

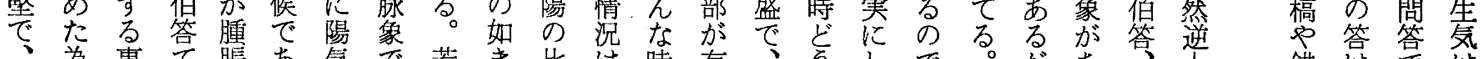

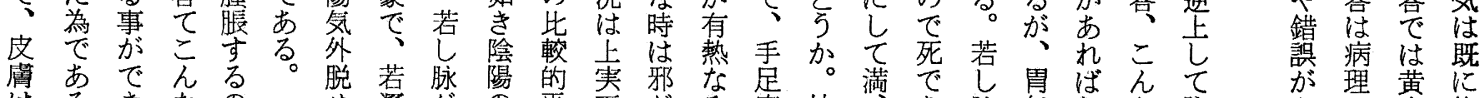

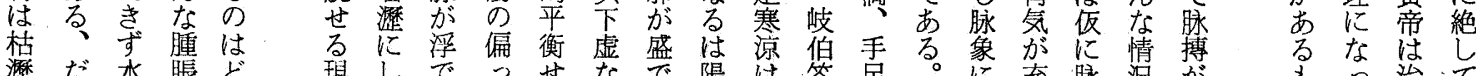

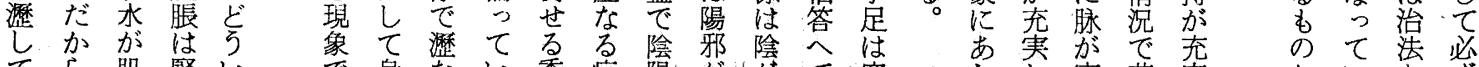

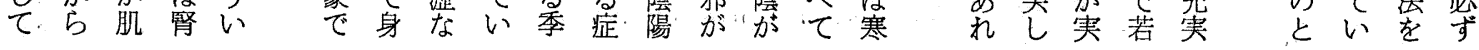

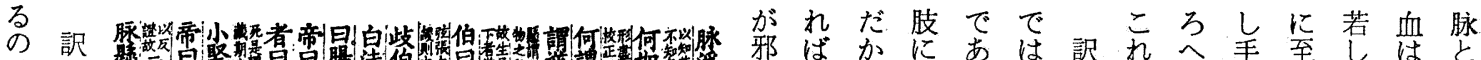

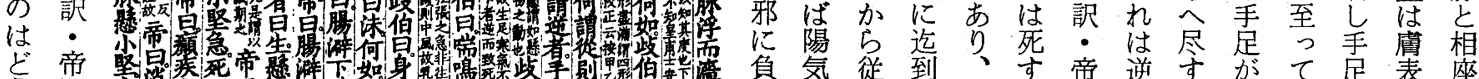

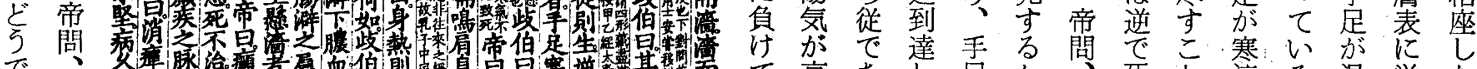

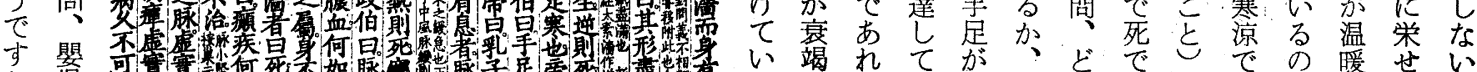

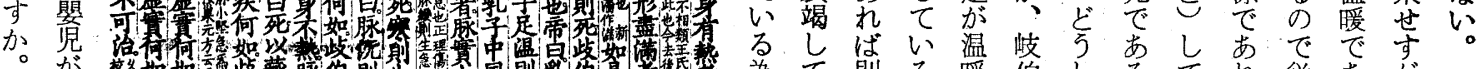

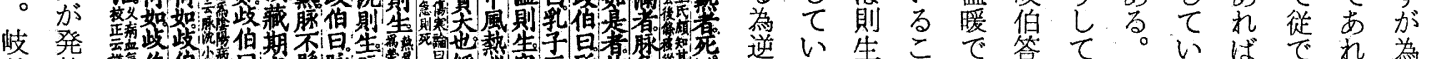

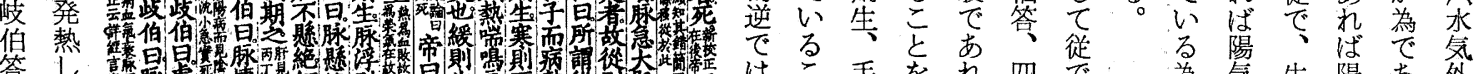

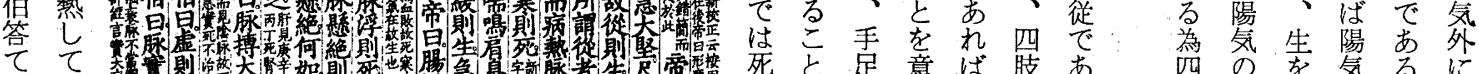

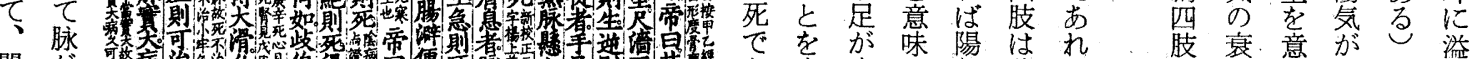

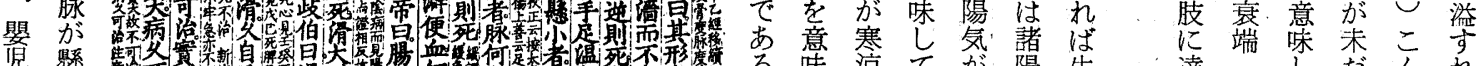

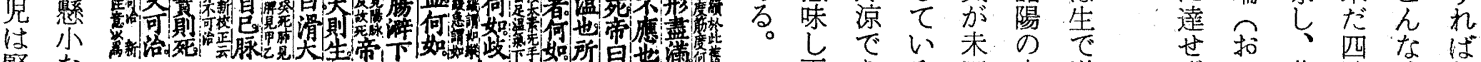
督な

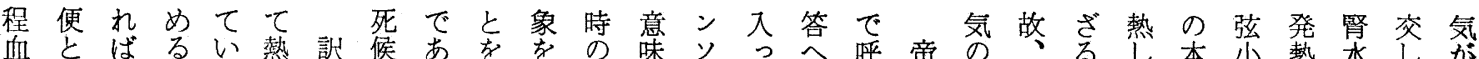

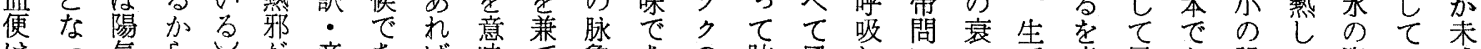

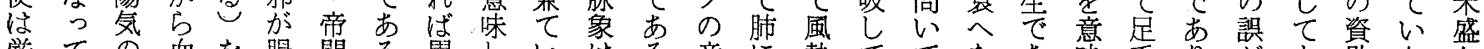

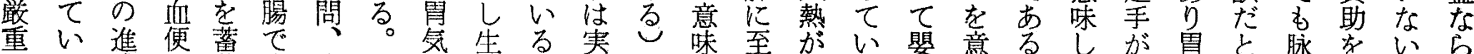

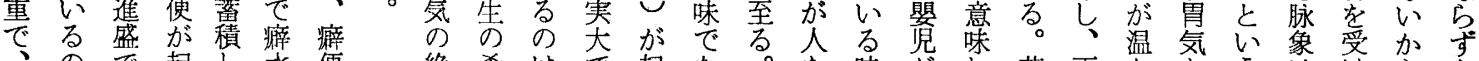

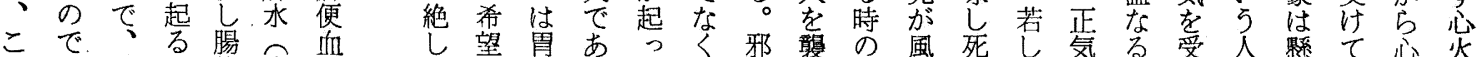

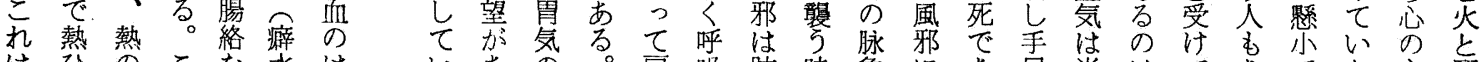

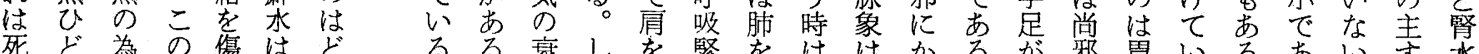

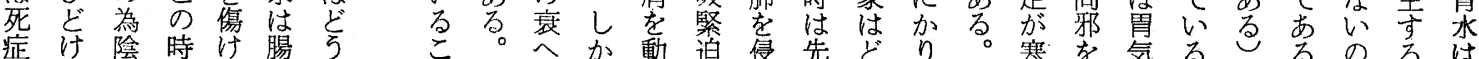

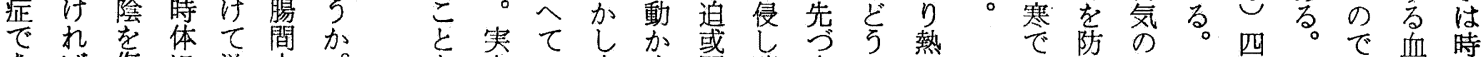

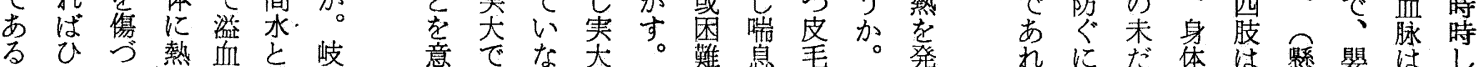

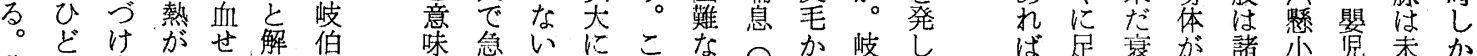

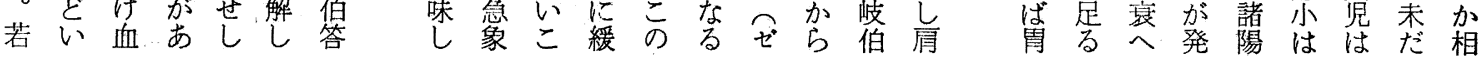

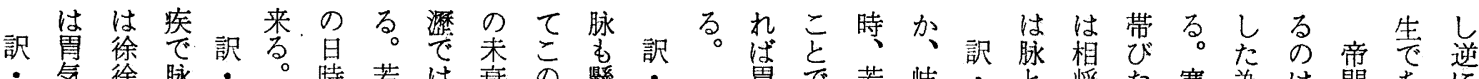

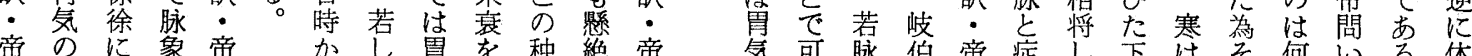

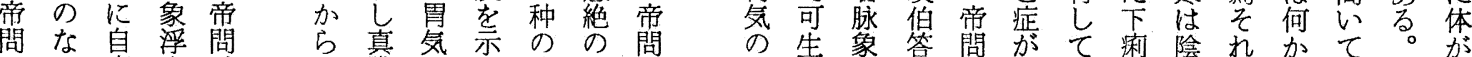

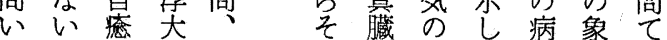

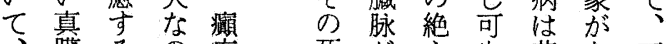
藏るの疾死が皦若な下

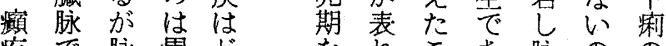
矤で脉異ど の死象気 脉症の市 象で小あ のあでる岐

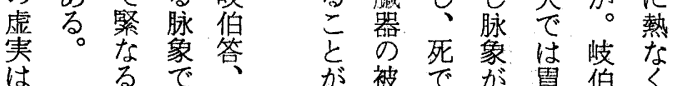
をれこあ脉のの

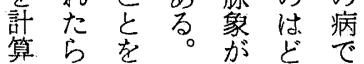
条条若滑亏 体 る 藏しし大かに 占被死象は肢な 出克あ 桵 気 答

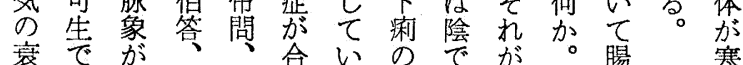
市滑下下含る時陰下岐癖寒 たる大浰な利な脉脉っ伯唯あ

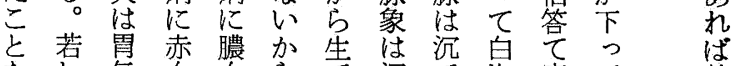

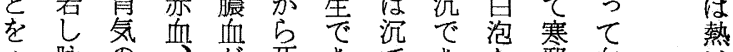

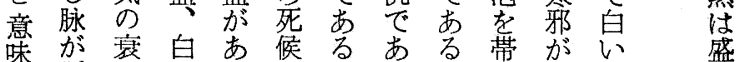

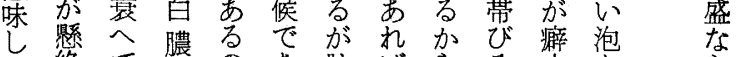
死絶て膿劣古脉ばらる水萢占

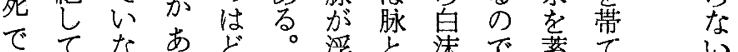
あいいるう症染あ嘖いて為 


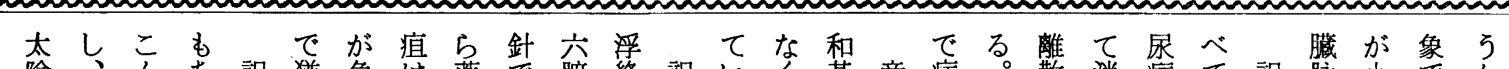

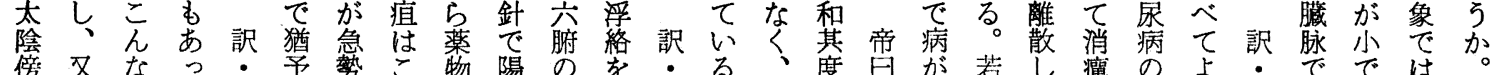

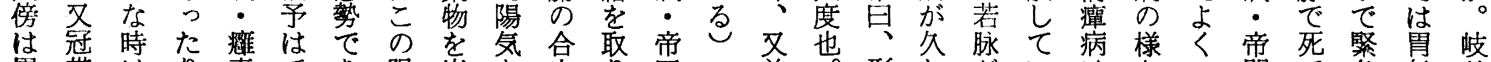

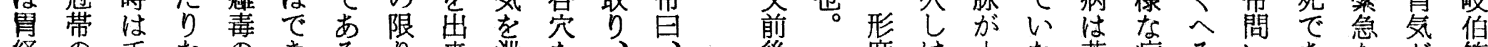

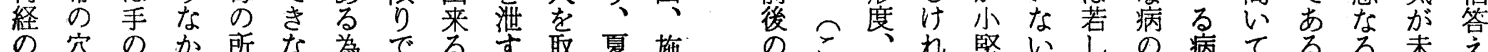

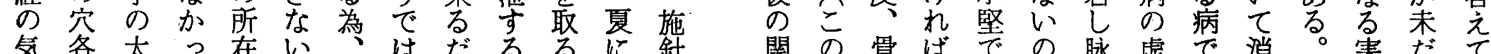

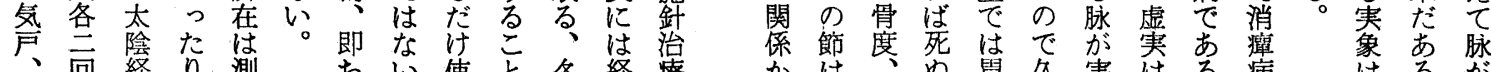

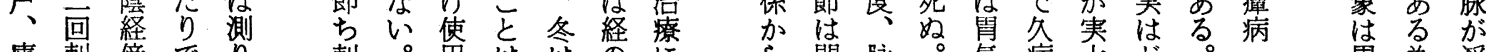
庫刺傍でり刺。角はは长

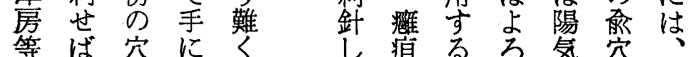

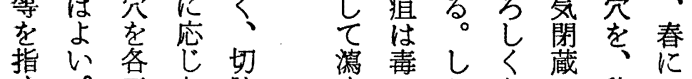

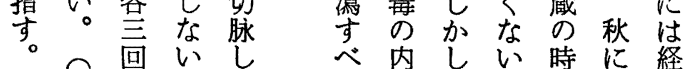

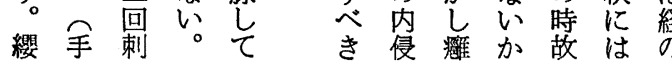

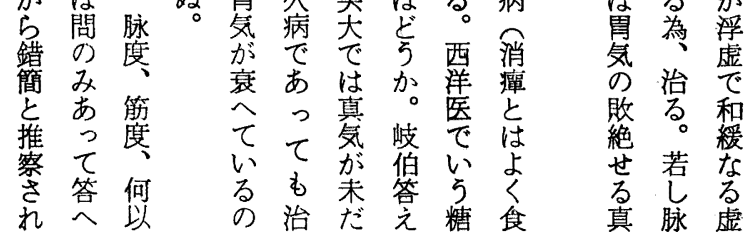

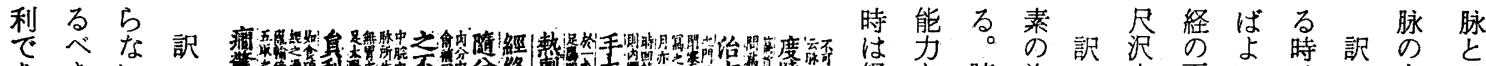
あ き

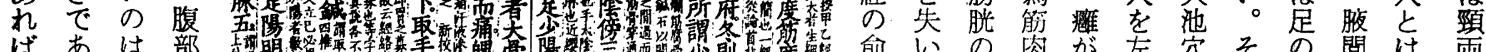

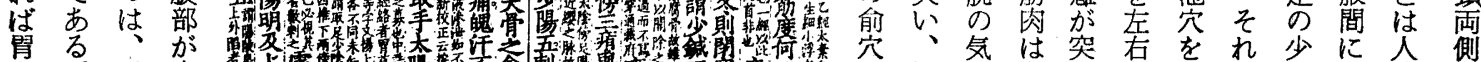

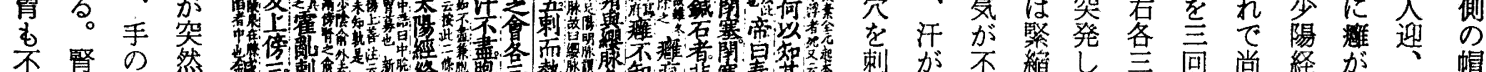

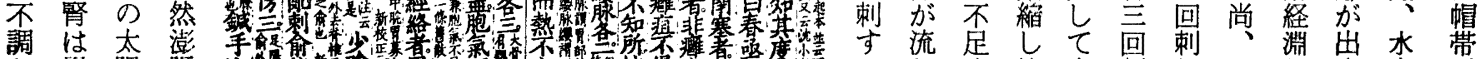

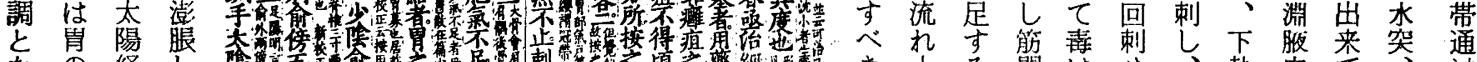

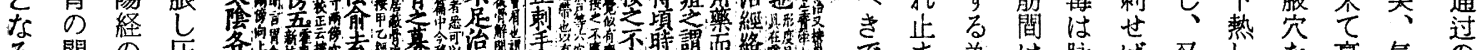

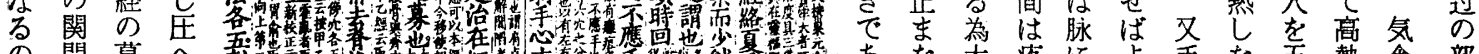

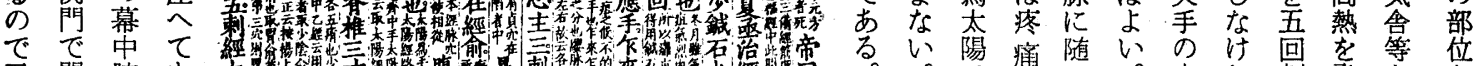

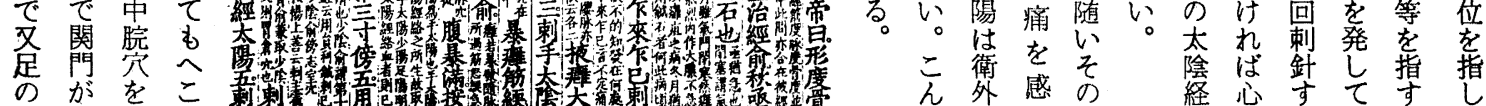

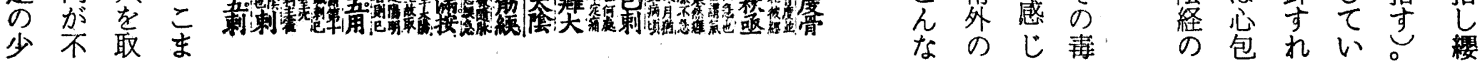

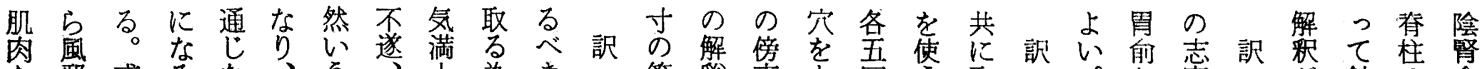

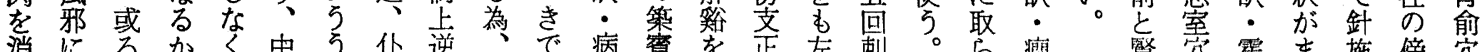

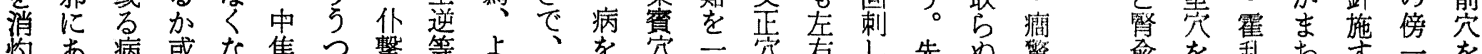

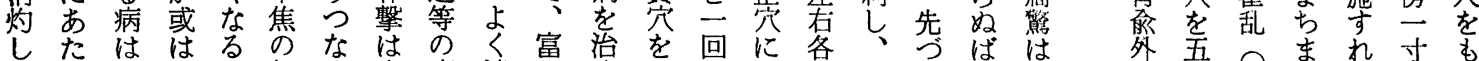

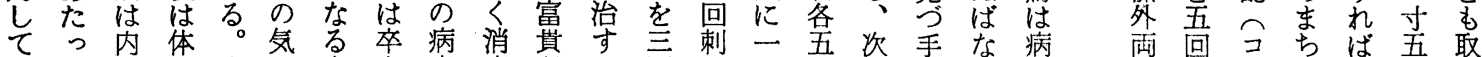

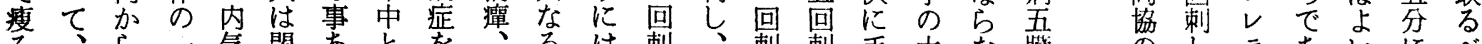

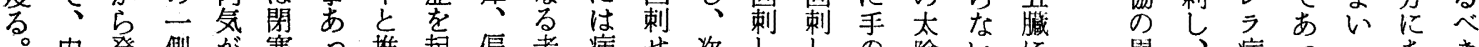

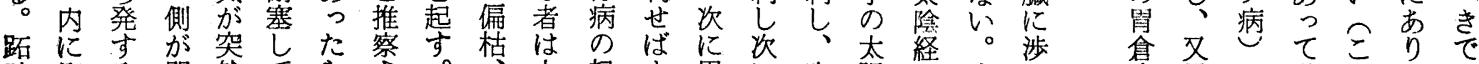

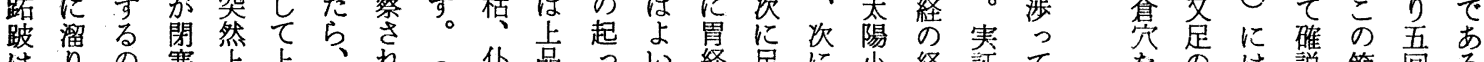

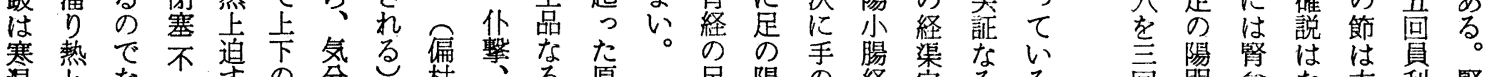

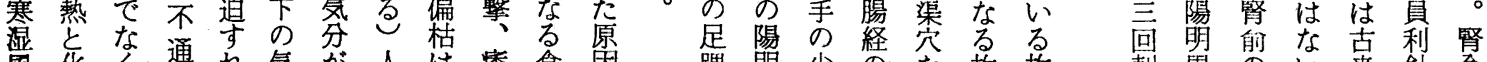

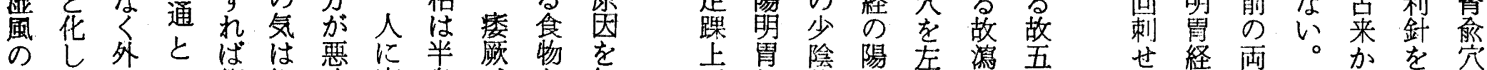

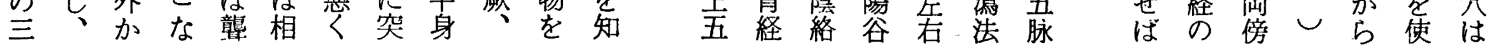

な生く裹 訳

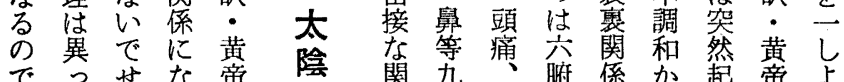

あてう問

る居少て

脾各岐る。

は号伯艻太

錐病答

苗卡它陽

筒脾病明

陽じとは胃

腑く霄同岕
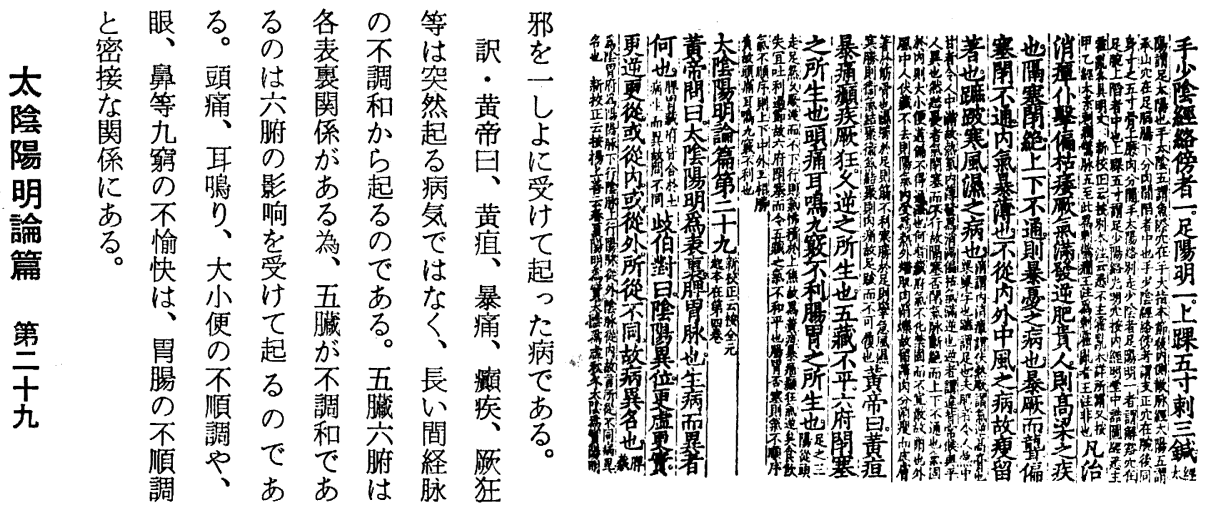


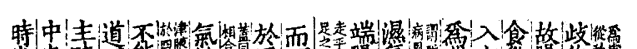

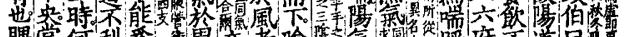

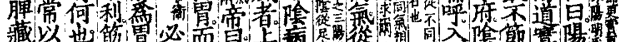

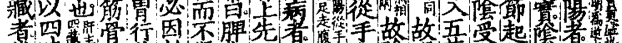

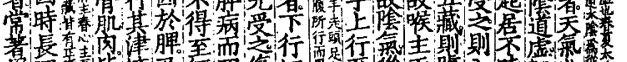

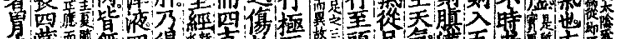

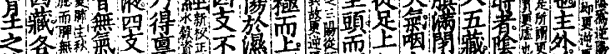

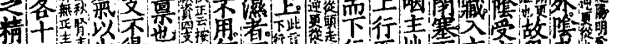

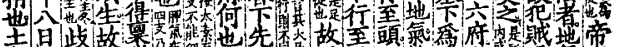

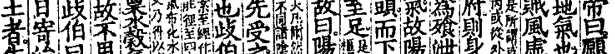

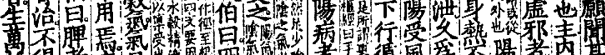

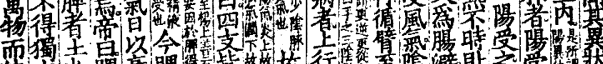

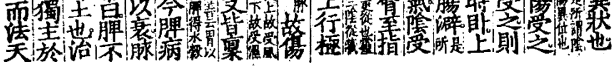

胃すには飲陽等はをを岐はも従あ陽 気る影陰食はの普与衛伯訳異逆るは

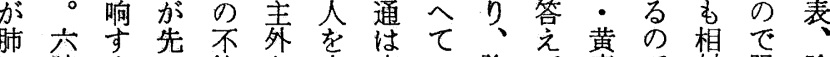
に腑るに節な害実以陰て帝で対陽陰 迫㤎。受制る导でるは、旦あ的がは

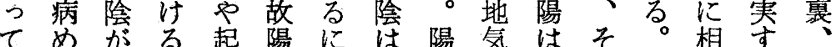

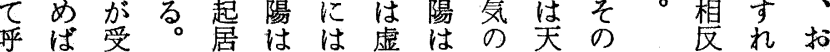
吸身け陽の先外で剛㠰気異泟 肪はた隹不に界あでくのるるて陰に 困熱病受順こかる陰人如所加は相

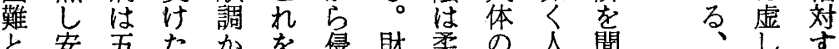
と安五た吕を侵財采病全聞

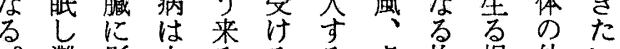
五 灘影六 腑 病。る。虚故根外以。
だし 方

方四関

病季篅

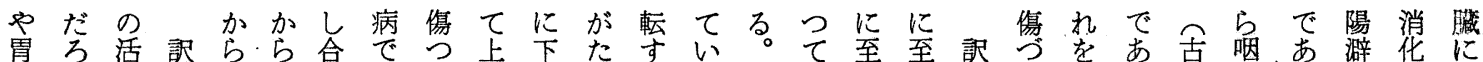

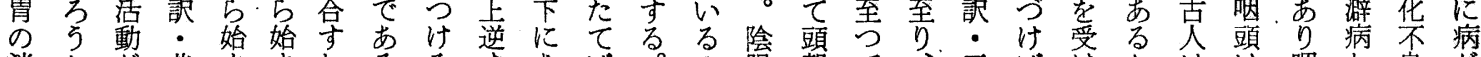

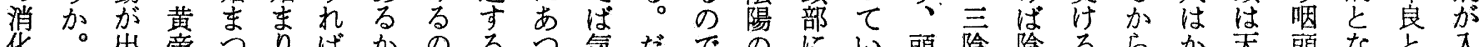

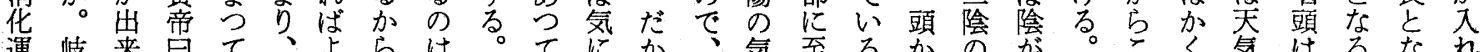

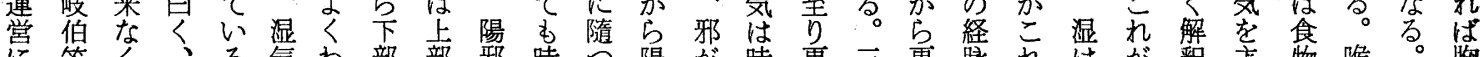

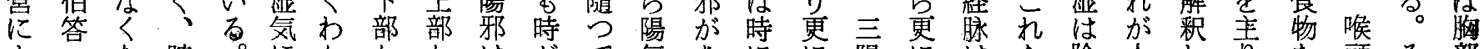
よへな脾。にかかかはがて気古にに陽にはを陰人新り

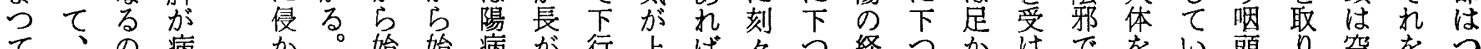

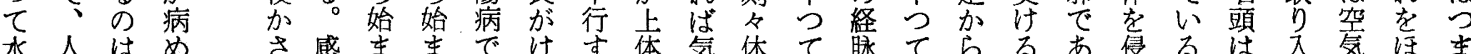

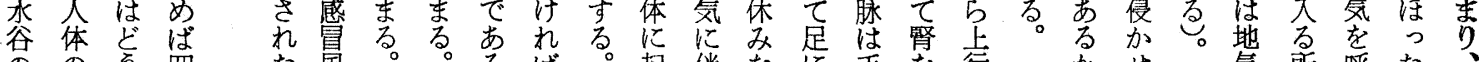
ののら四た風。。るば。起伴なに手を行なか世気所呼た 、

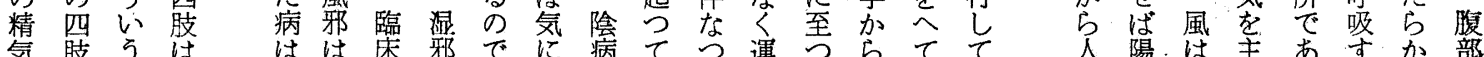

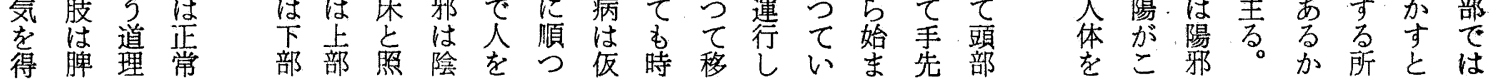

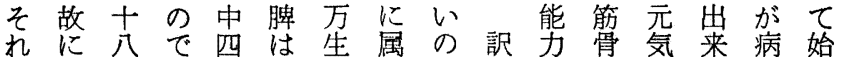

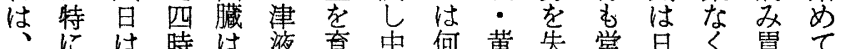
脾二脾の持成央故帝っ意になの活 は季の中べ四すにた問てを沉建動 胃節 寄どて臓る 位ろいし失にば液力

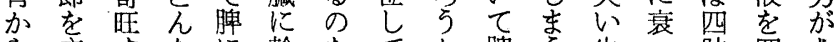

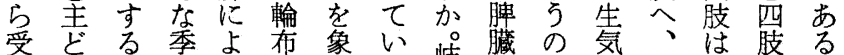

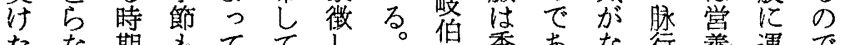
たな期もててして。答季あな行堲運で

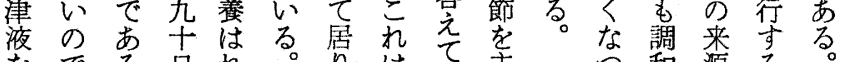

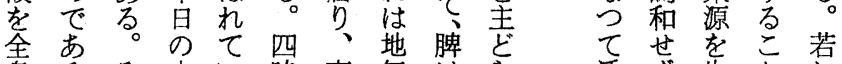

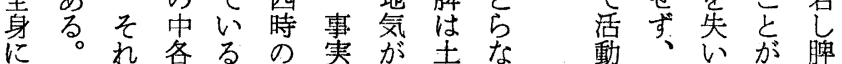

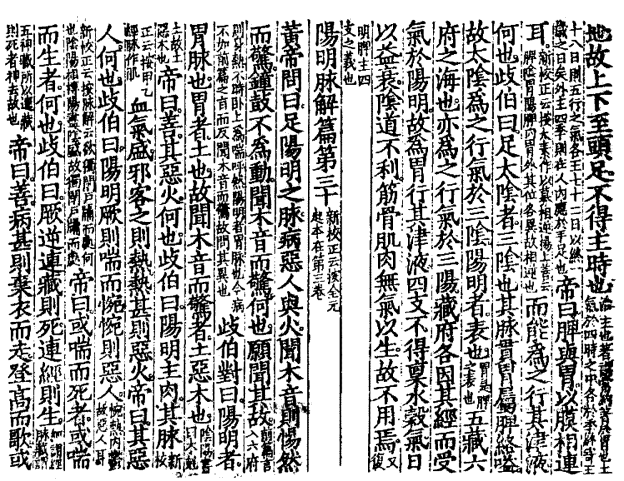

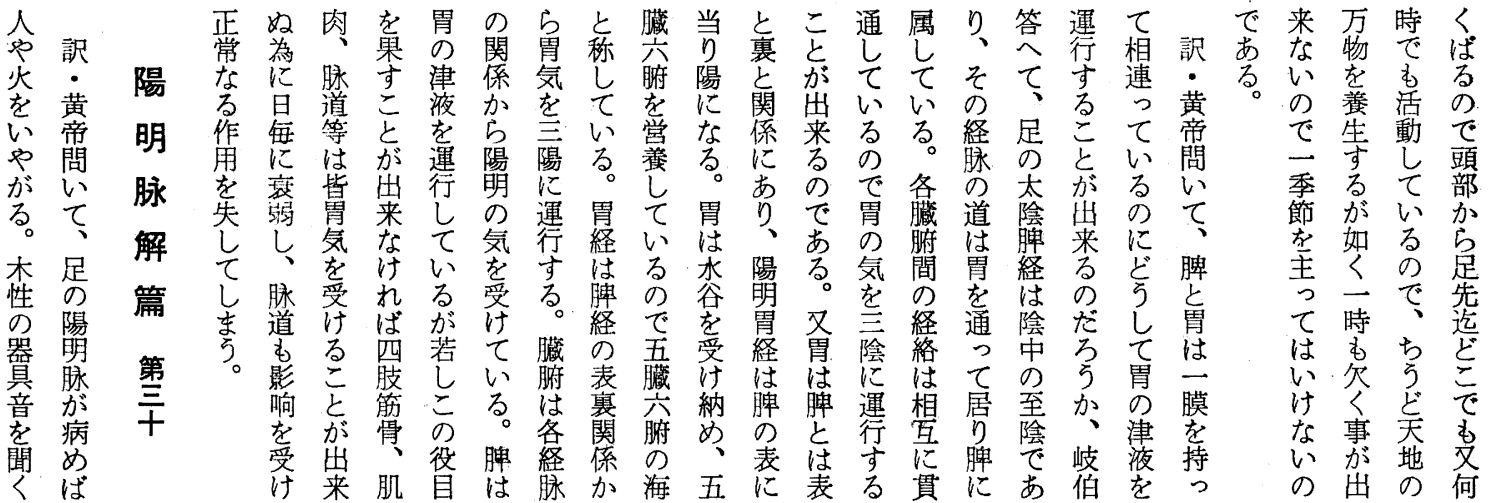


故水すおい

加訳をぐるる。

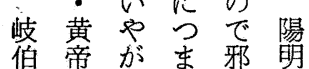

答皇る

光くの発害文

陽他あ熱袁々

盟伭る。等受の

は心资る貿

内や な

熱方 る゙ 気多

をの、だ血多

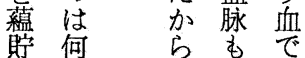

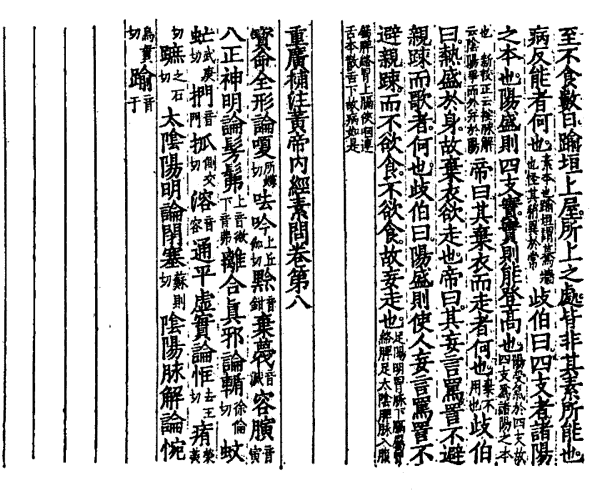

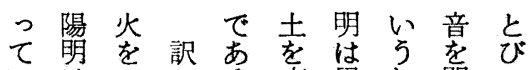

小は心。る克胃わ聞っ

る三や黄。㤗経けいく

の陽が帝・るでだたり

でのる日

気 の

故吾方

木行少な恐

音は岐と卆

聞性伯す な

けに答な学

恐方ての 鍾

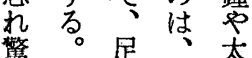

の

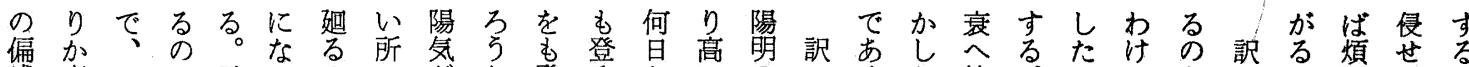

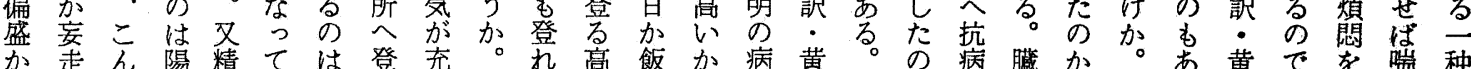

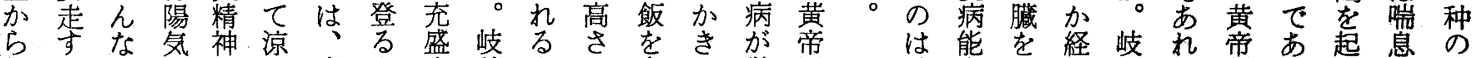
る時ががし病よす伯上は食和厳日

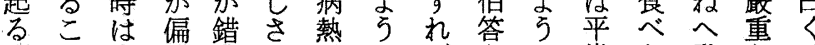
病と食勝乱を驾にば党に常な登な 変恶欲し求肌な四てな之かっるわ であも熱、め因る肢、るするた時か

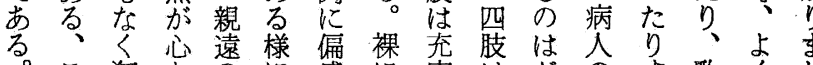

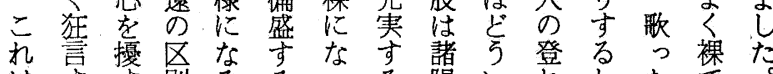

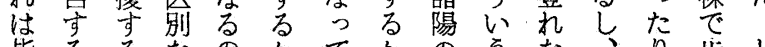

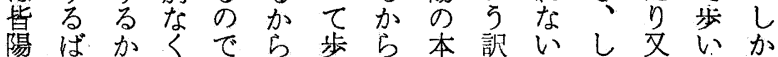
病孝侵复答死問る。す、病変

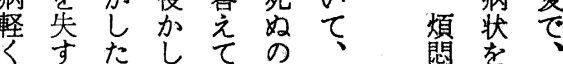

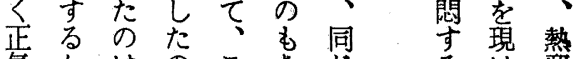

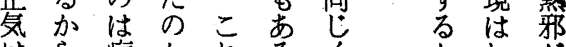
はら病加杂く方しか 袁ぬ死は重よ病は喘他心逆

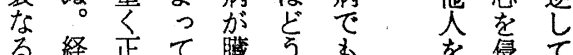

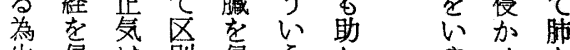
明加ら怒あ裸き高でだ所かはたし生侵は別侵らかが

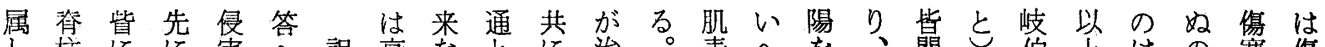

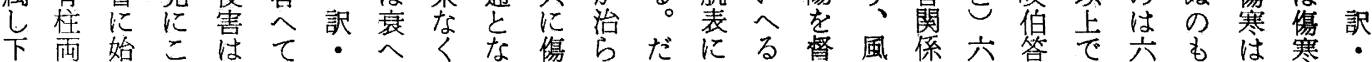

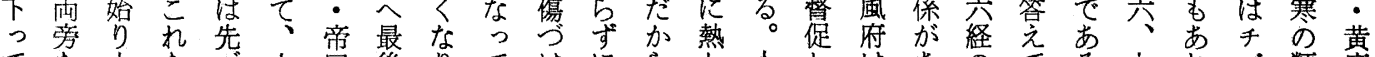

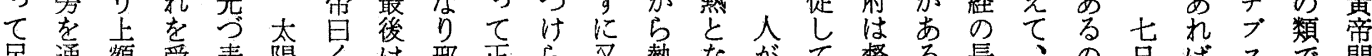

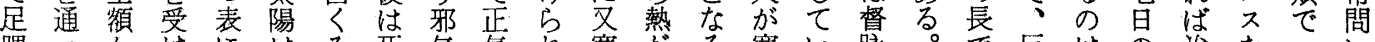

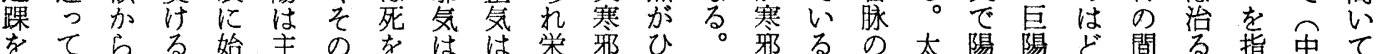

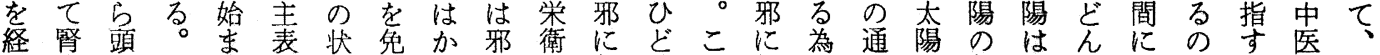

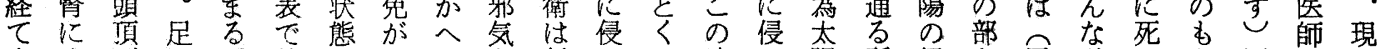

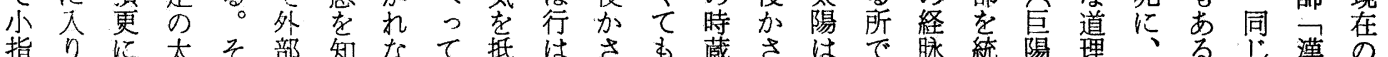
先下下陽れかりい旺御れれ死汗れ諸督は摂とで治。手方熱

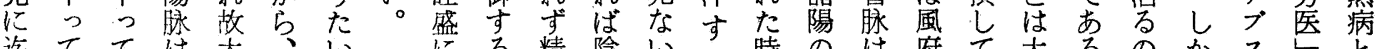

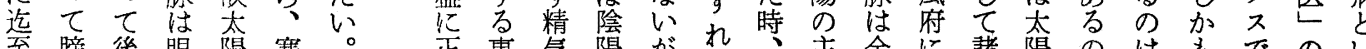

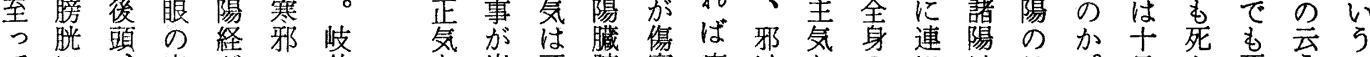

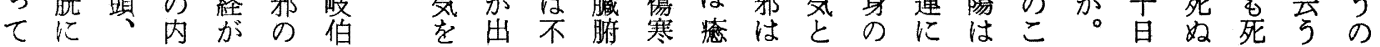

熱

論

篇

$\stackrel{\text { 第 }}{\stackrel{ \pm}{ \pm}}$

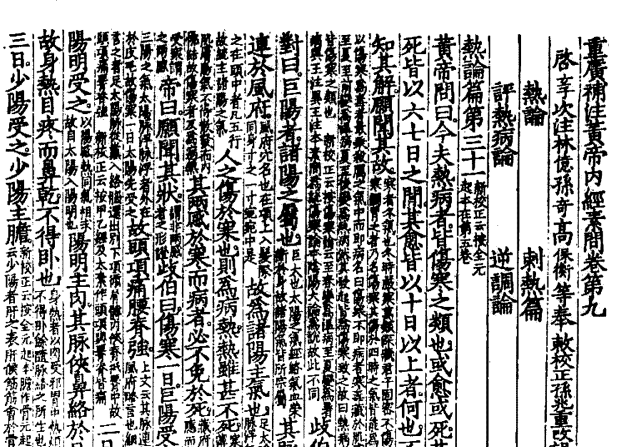

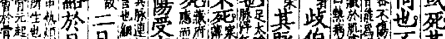

時受みる、肩経 は邪た 章 体時揫た学 の 症 5 绎状 5 亿外

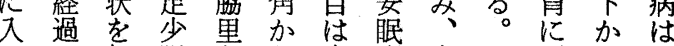
て 竞起陽通始陽来体が至ら始明

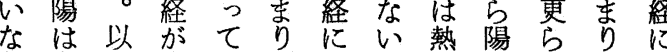

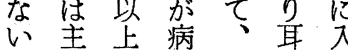

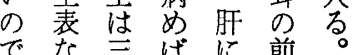
でな発る 陽胸属後足

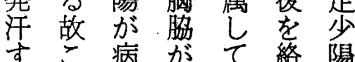
机の病架て 絡隄

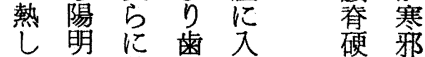

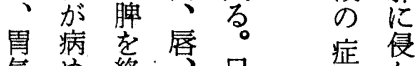
気め終足足状尘

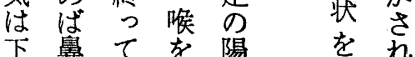
行畺で常陽起た 
第経ばぬか栄病で満はす耗病かし少化液り骨りる経ば

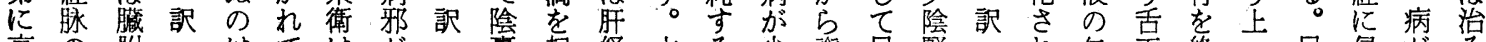

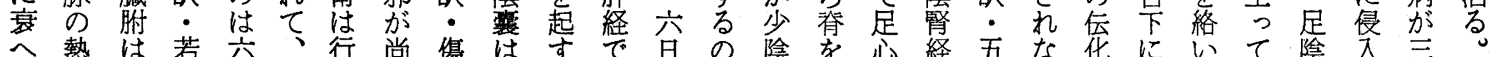

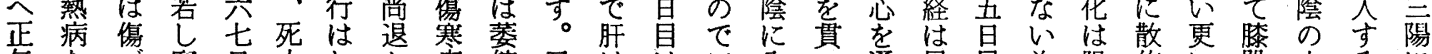

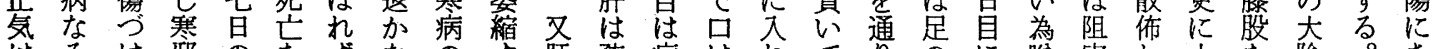

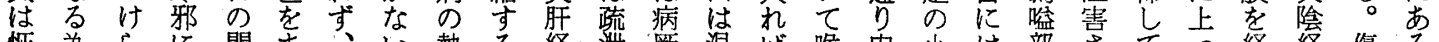

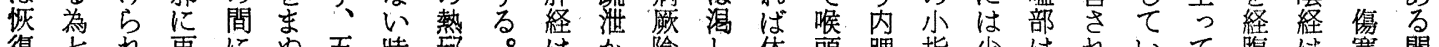
復七れ再にぬ五特邪。はか陰し体頭踝指少はれいて腹は寒間 白て感あが藏は茷 る老い㟔机壮六六 の過なれのな調胕経 でせがるでい和五を

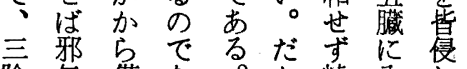

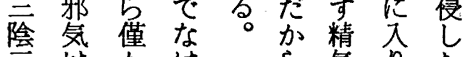

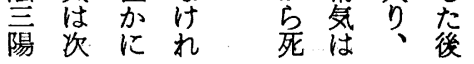

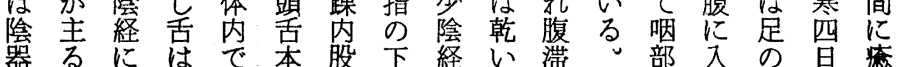

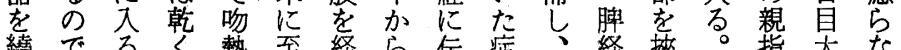

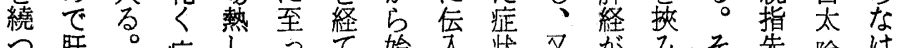

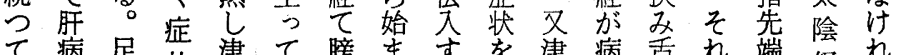

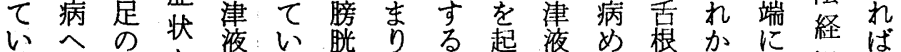

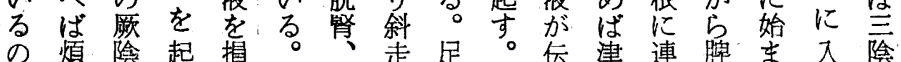

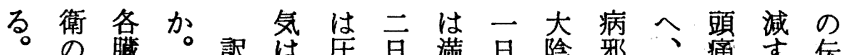

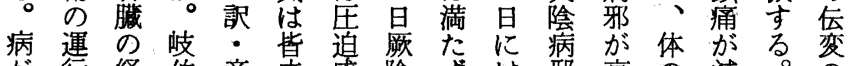

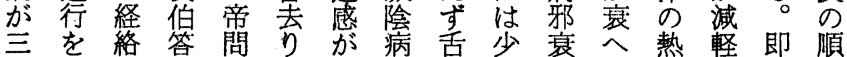

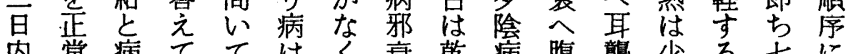

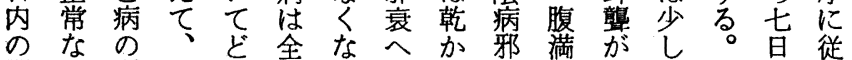

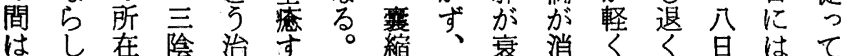

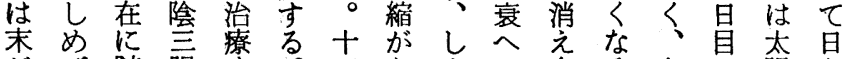

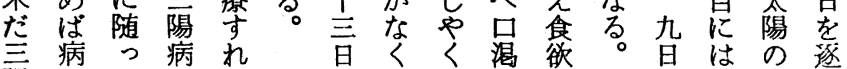

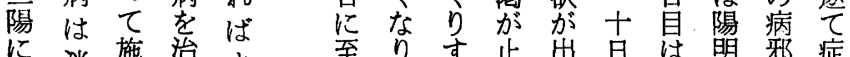

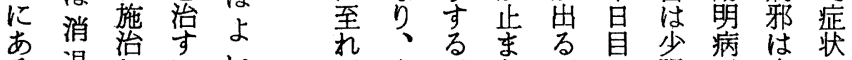
の退し学は心

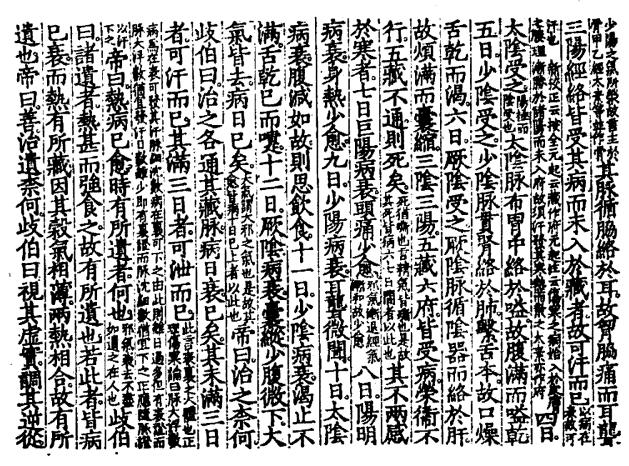

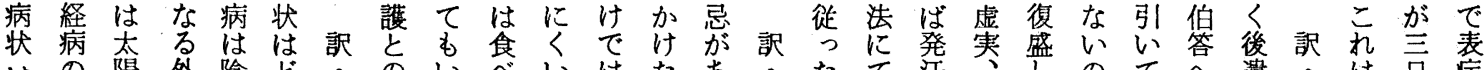

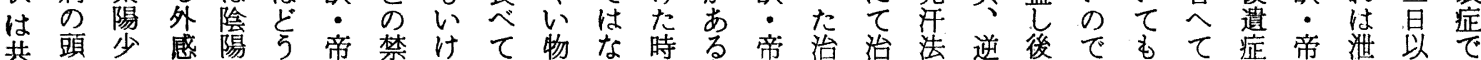

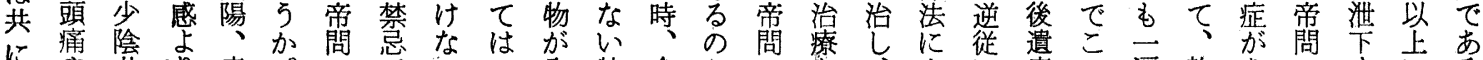

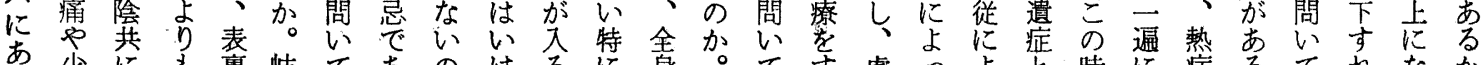

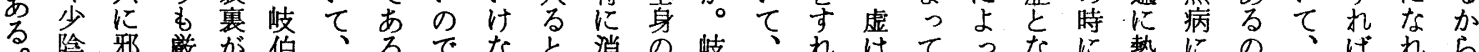

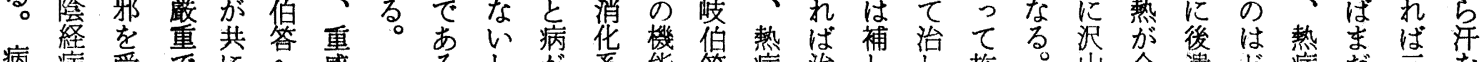

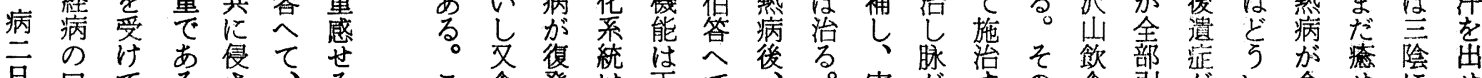

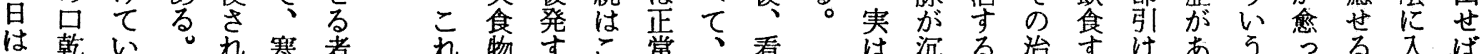

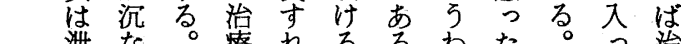

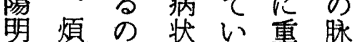
太満で第て感象

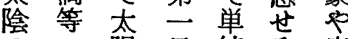
の陽 日純る症

はをるのに熱護

病 沢故時復病卡

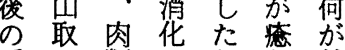
看聵し华禁
泄な。療れるるわた。る

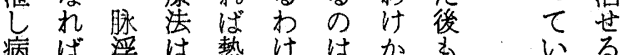
病㴬热势尚台名

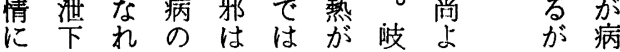

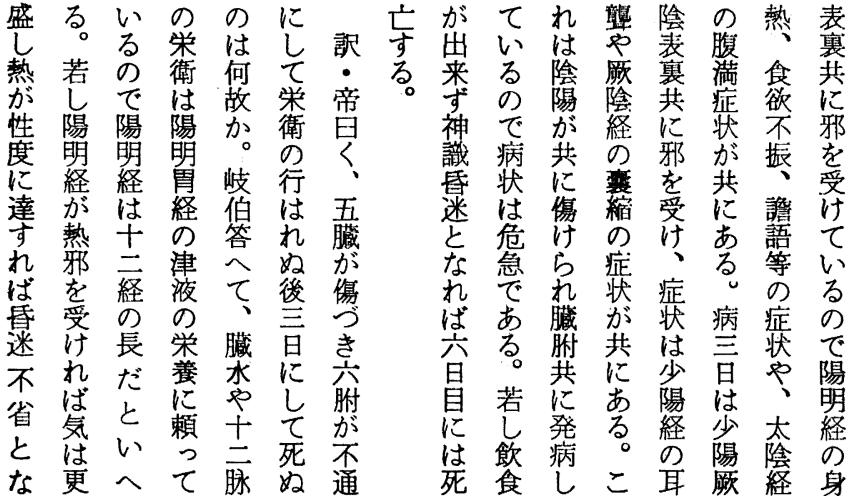

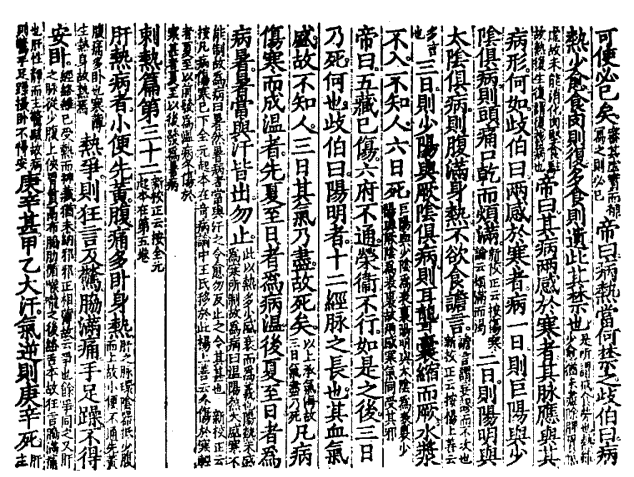


下る゙すお なて

が。れりい桶

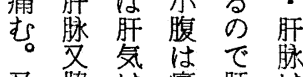

圣熱のは痛胿は

熱の乱み に 陰

為骨 璱る が

四通点様古

肢警なな゙て

躁い顛る。面

動る 病熱情腹

るた㤎等色至

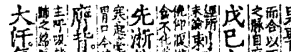

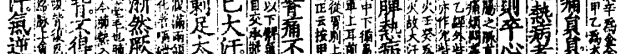

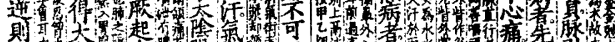

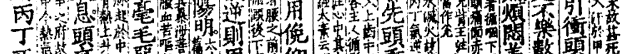

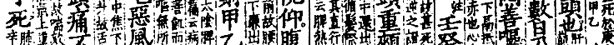

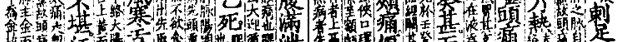

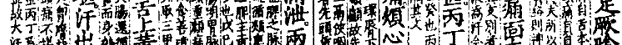

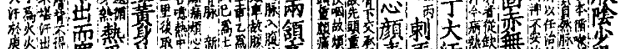

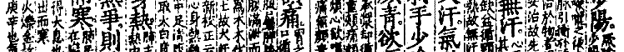

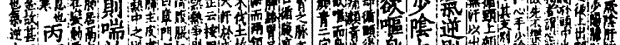

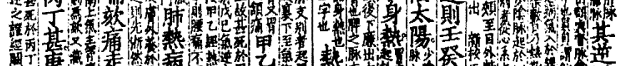

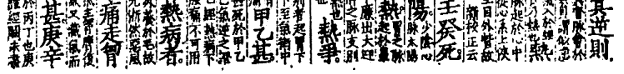

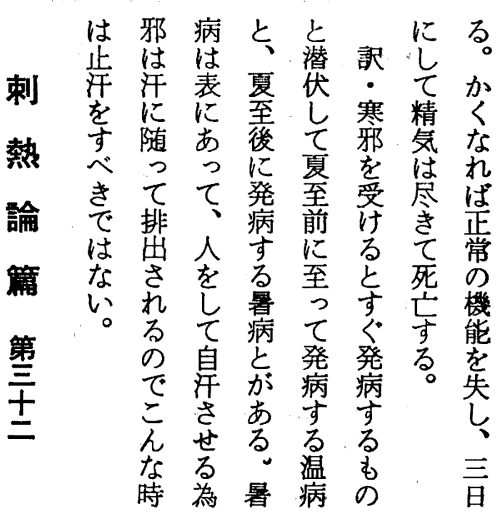

る。色煩痛卡れ

脾青を起か脾

矶出起吉顧

萠出す。顧

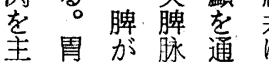

る 気病 は通

が肪㤁て

脾逆胿注る

熱て侮でで嘼

勢て侮でで㽚脾

れ喁顔る重は発

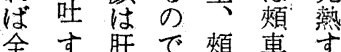

のば日はにる痛痛体さ

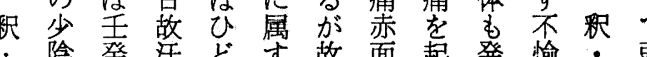

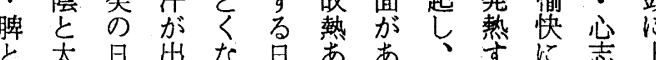

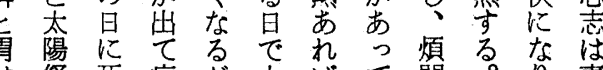

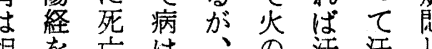

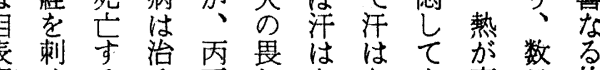

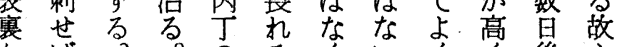

な ば

小治右早所な 療気水あ る琵はる終積 あ は埍旺加癸心にれ 手れなる な病水な液圣頭心身先

っやをすはのるいれ䏦

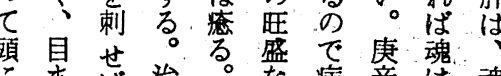
上小ば治。気る病辛、魂 っ衣に唹旦ひ金在宿 た起。はつで と蛅出

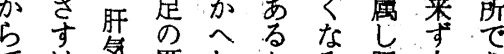

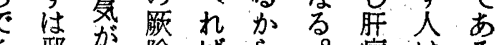
あ邪陰ばら。病忏る 気超庚大東 安 経

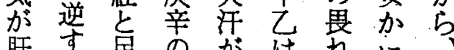

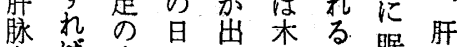
をば少にで昌眠架 頭陽死ばでで熱
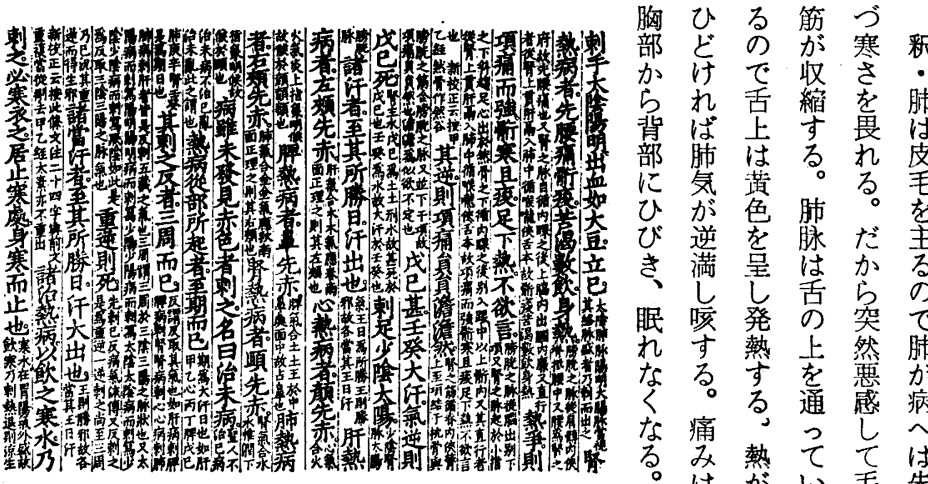

せ死病な日車が胃耗身 た痛経亡病訮あなす

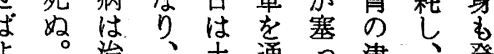
針る戍市通て萑腰熱 治若己畏て張を痛す に若は标少運しる。 は足気 の 所 の痢卞府熱 の㤎旺ででする仰が 太逆盤古両る事出ひ 経れる か墽围出な们 とば日ら痛脉来くれ 陽甲故病む!はななば

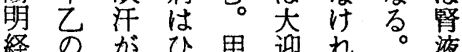

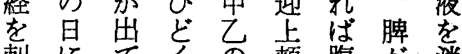

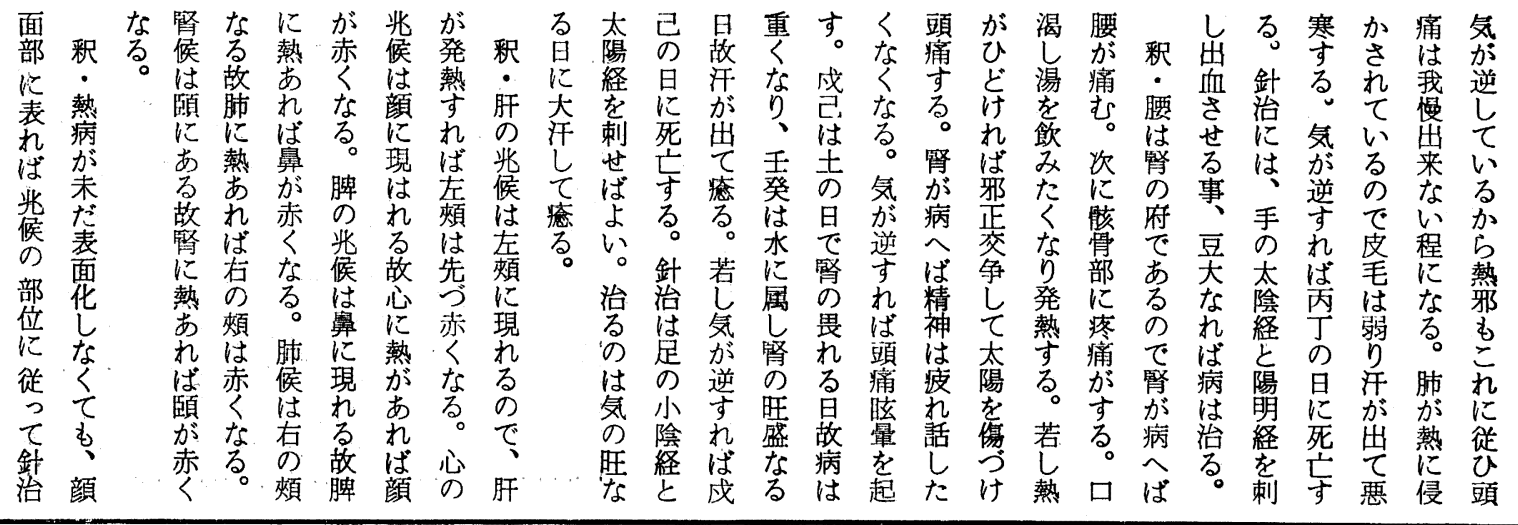



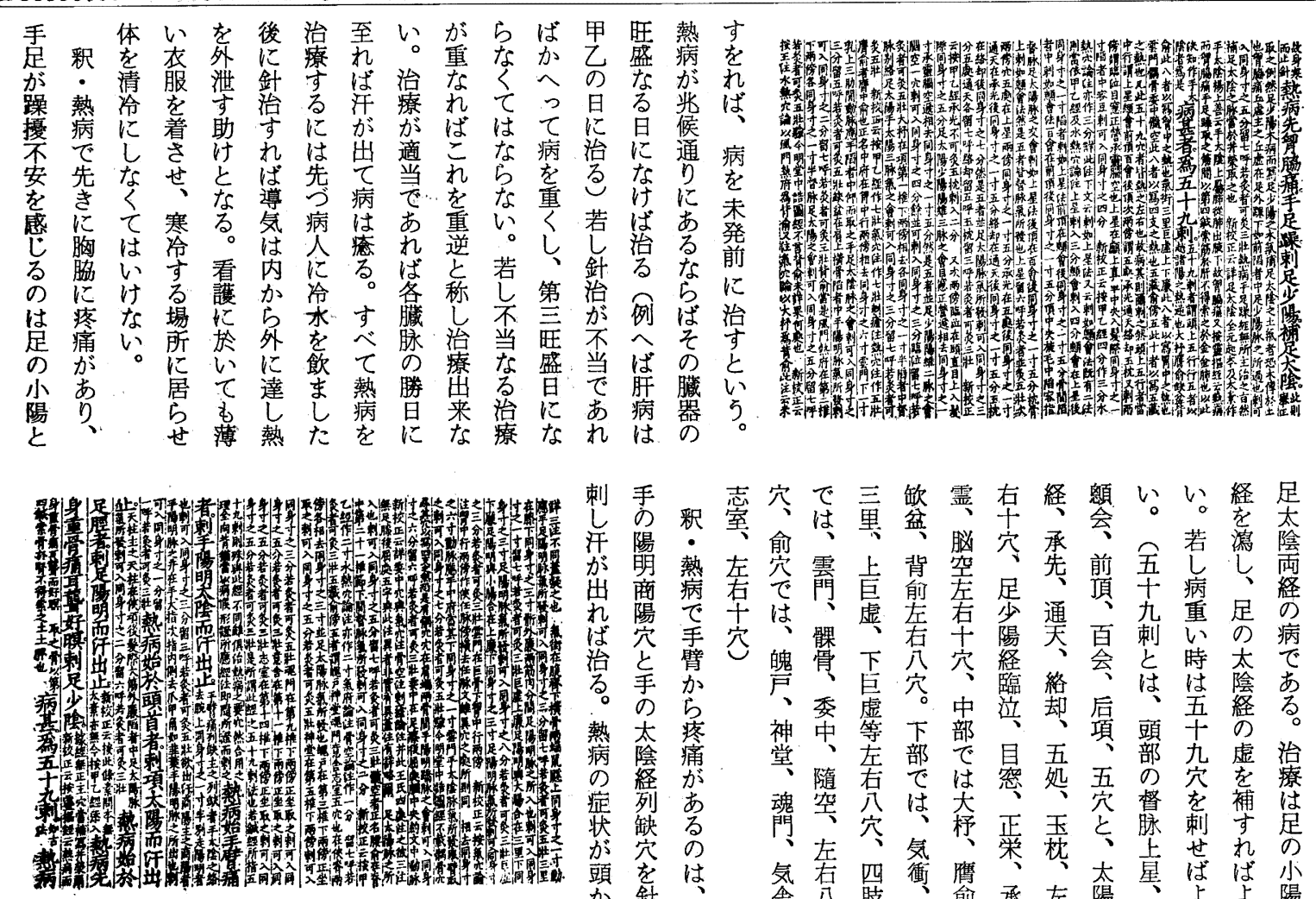

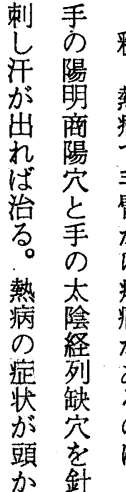

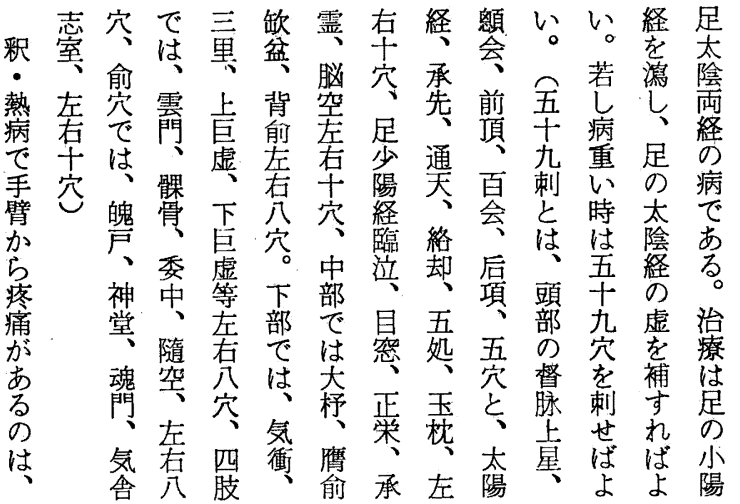

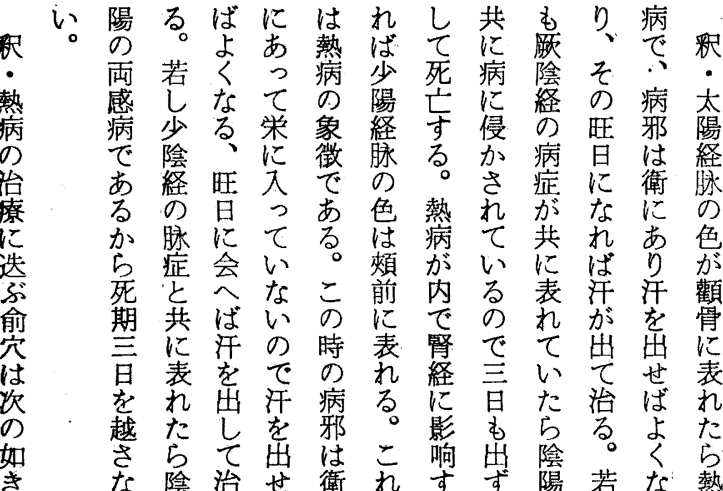

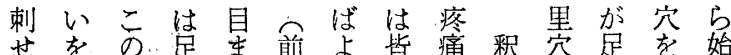

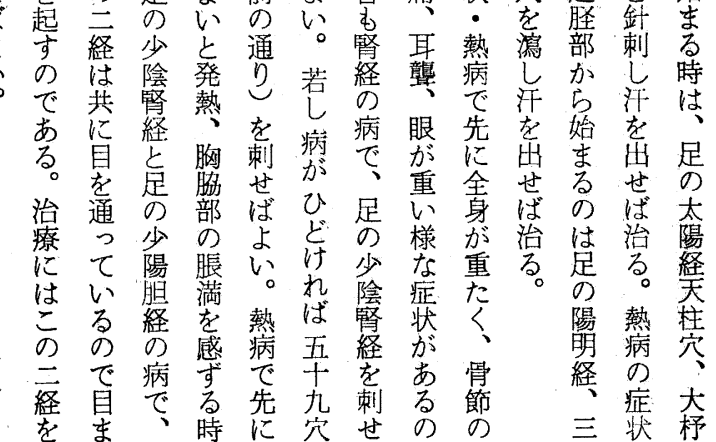

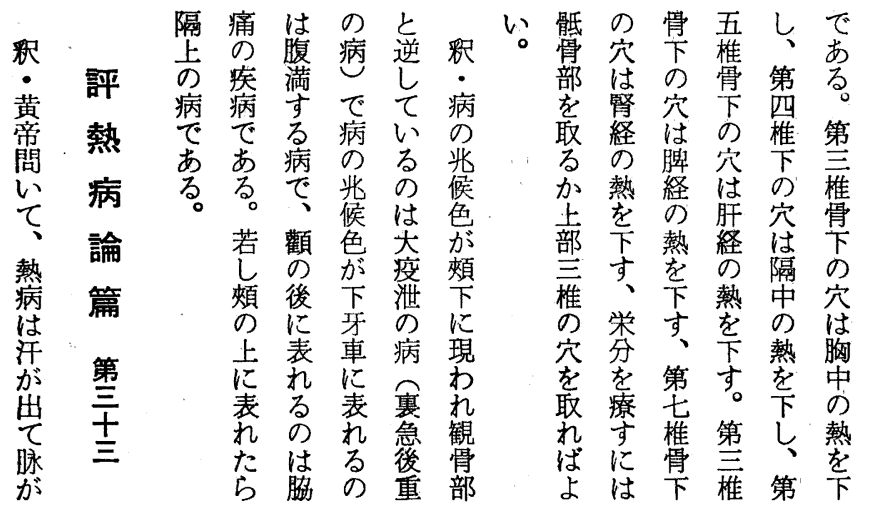

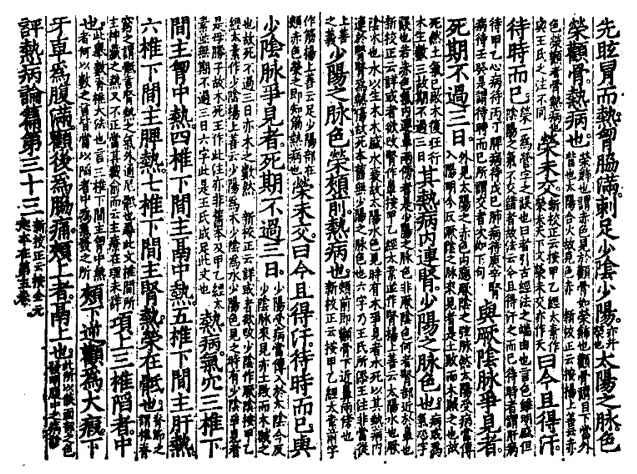


に病精上水た退陽な涼陽のいし静

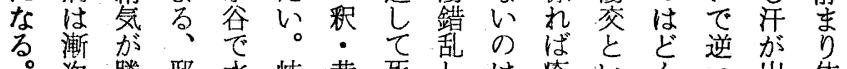

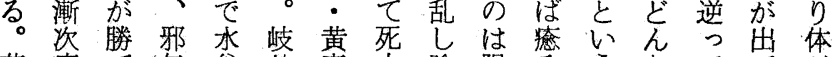

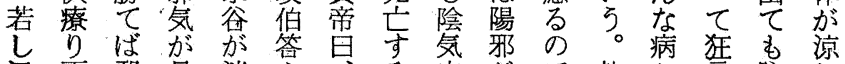

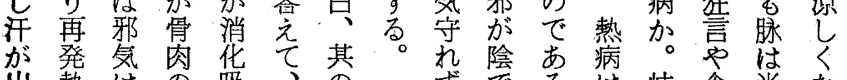

出熱はの吸、の

たせ汗間収人詳

後ずとでさ体細

で攴精れのな

も飲緒気る汗る

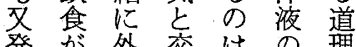

熱進に争精来を

等出出気源聞

ずでるは岐食党な

邪交㤎汗售欲躁主

はて氮落答がにて 病

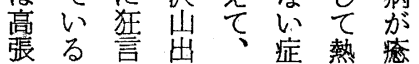

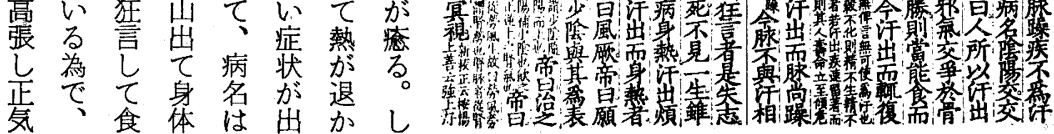

衰陰しが陰るなか

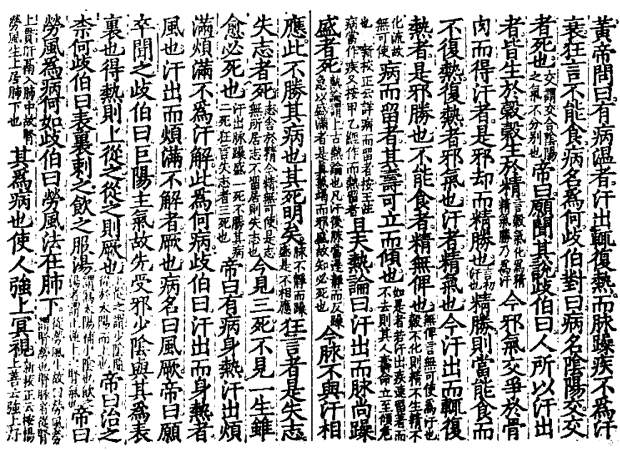

詳上のが解症ててが者党て死志は直でしので論ばるず谷にのの

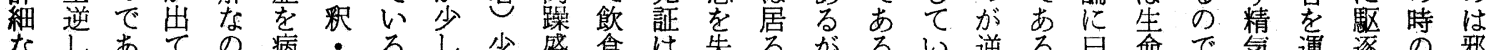

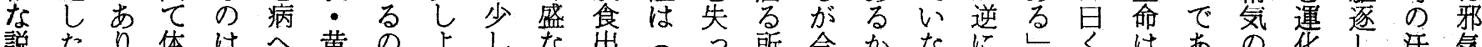

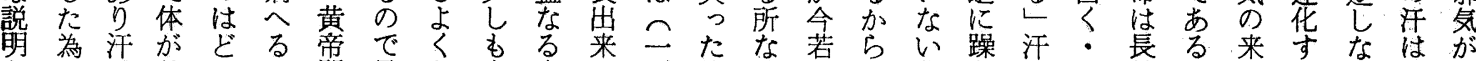

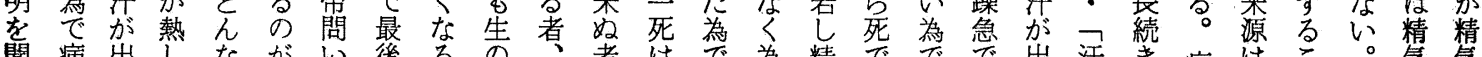
聞病出しなが心後るの存はで為精でで出汗き病はこう気気

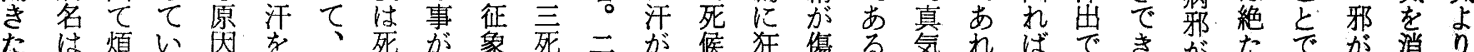

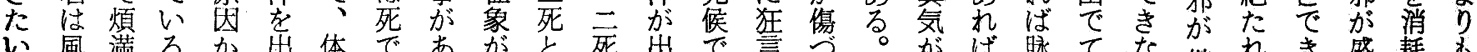

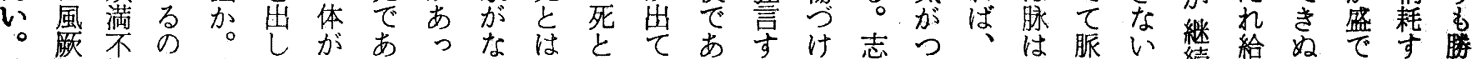

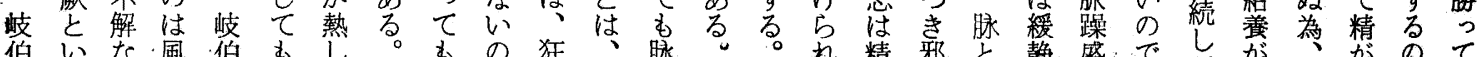

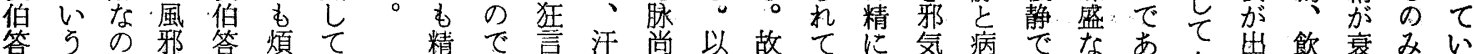

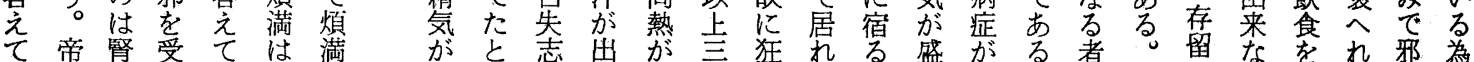

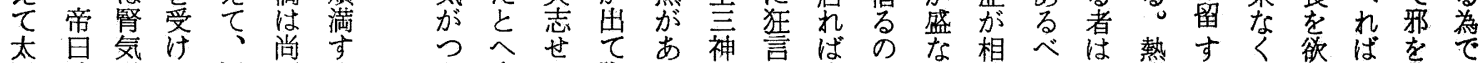
陽く怔た汗不るき病る眿っの䓌での想き死病れな世水外こ

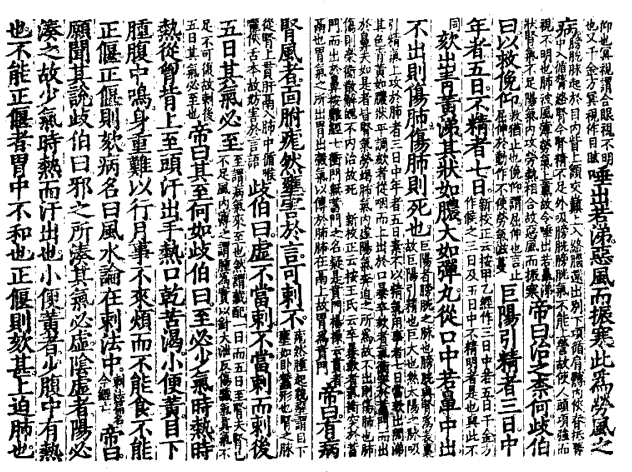

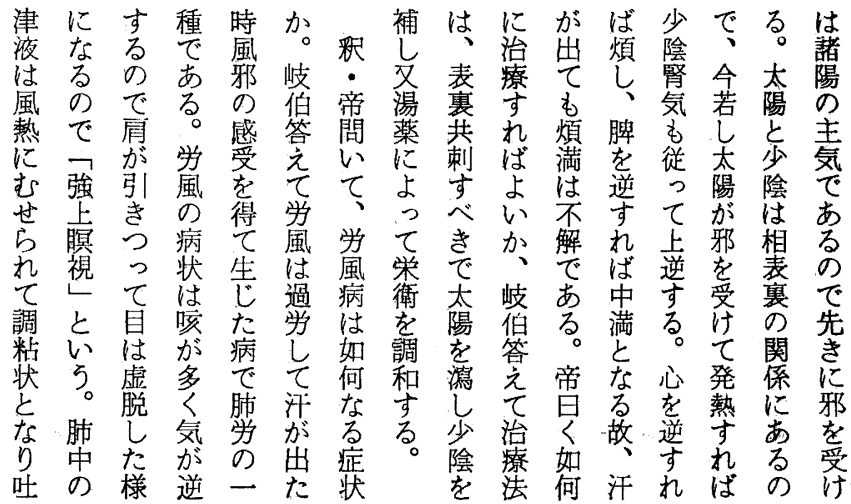

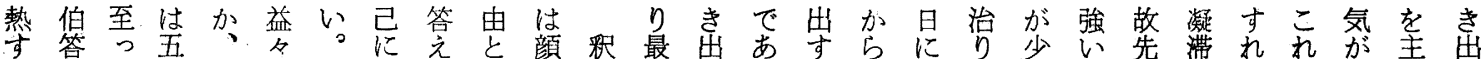

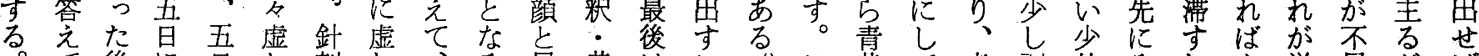

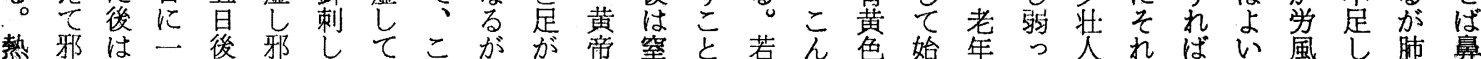

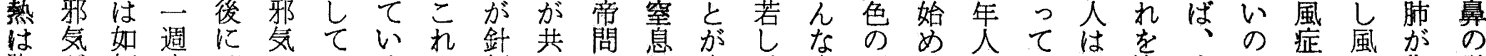

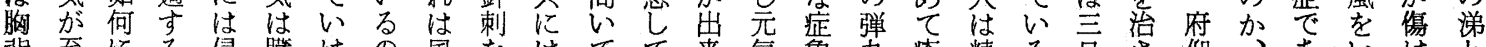

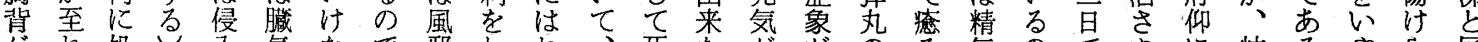

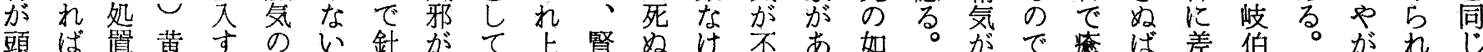

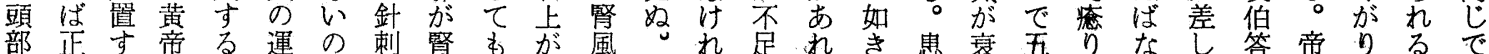

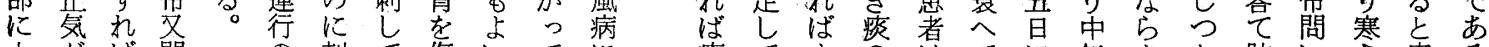

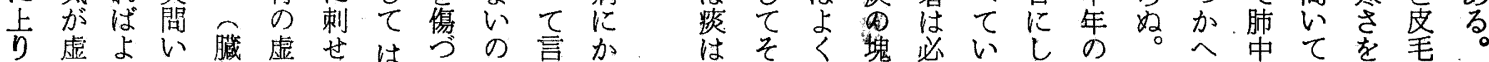

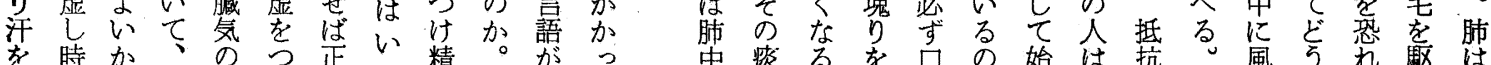

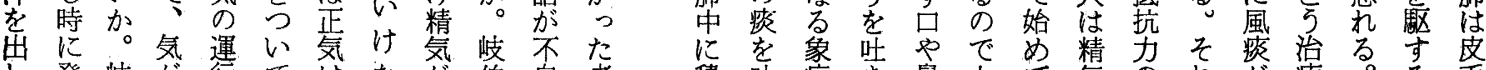
し発岐が行てはな伯自者積吐症き鼻七て気のれ势療。る毛 
$-10-$

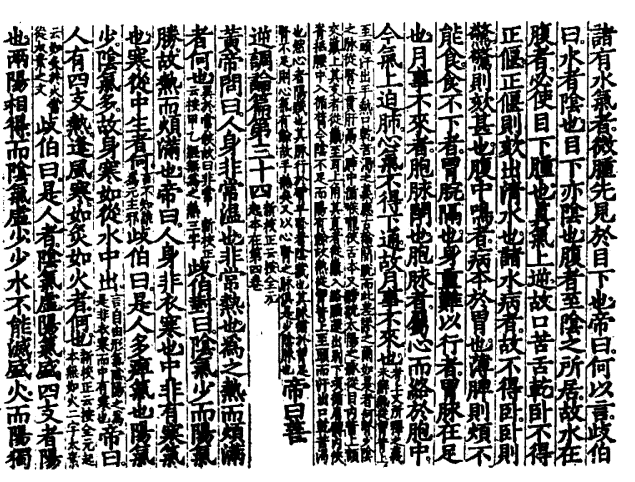

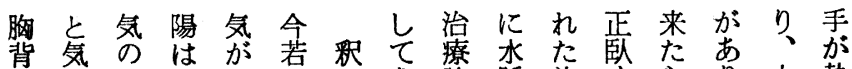
がは生こ虚し!古論腫為守らり小熱

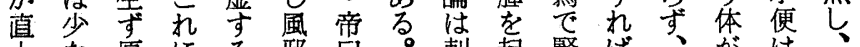

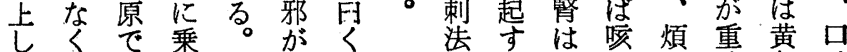
てなあずこ腎説故吉悶く色は

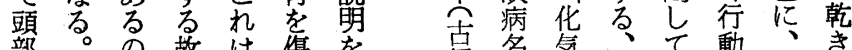

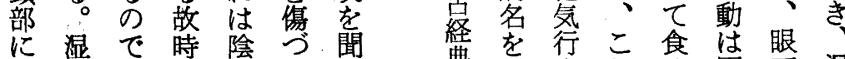

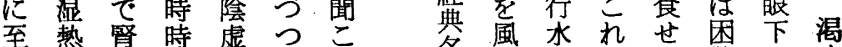
る 至热発等け ら。

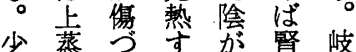
腹すける虚は伯 にるら。宓答 熱の゙る腎ればず 精て

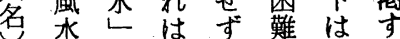

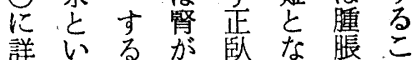
細ら事傷でりし 苦

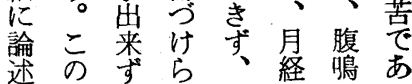

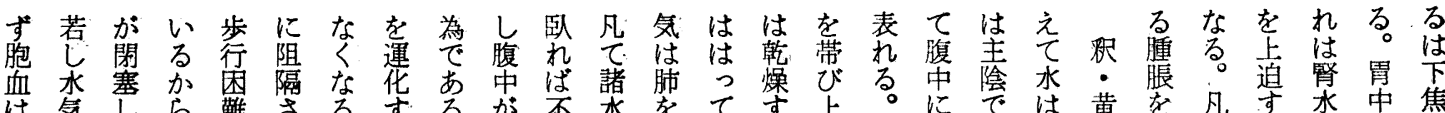

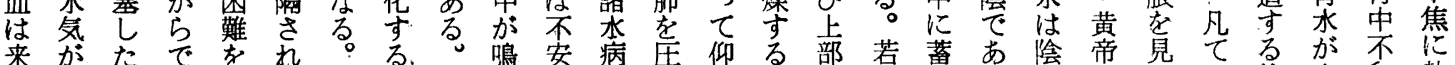

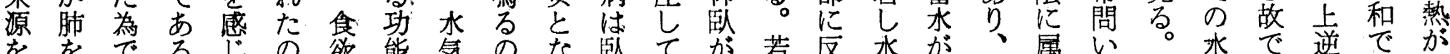

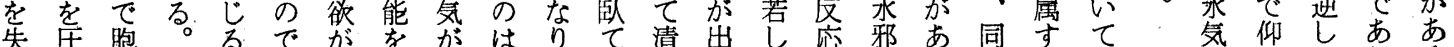

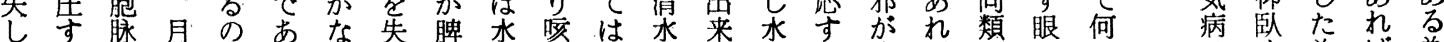

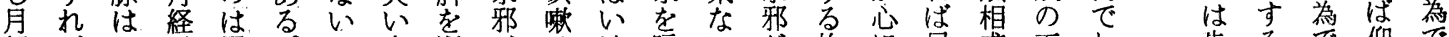
経ば心忍胃。の食犯がはけ峐いが故に目求下しで仰で

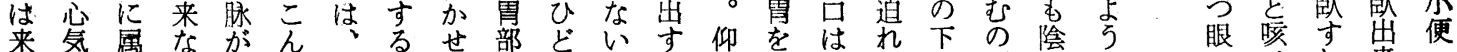

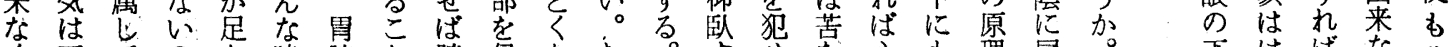

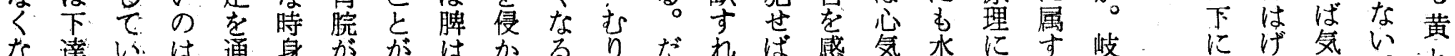

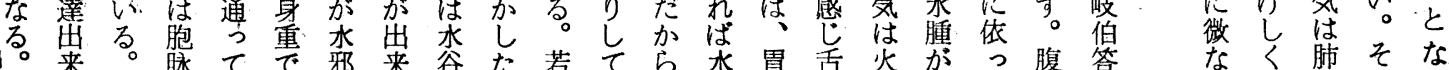

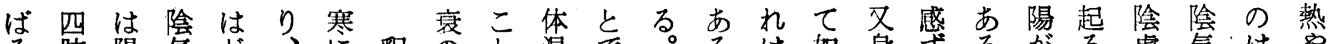
肢陽氛 熱発熱

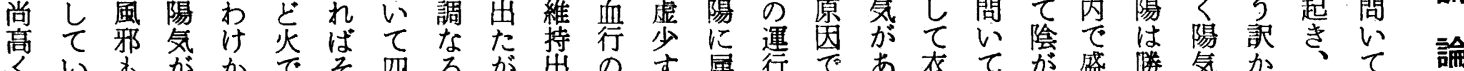

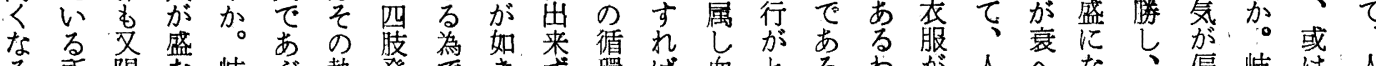

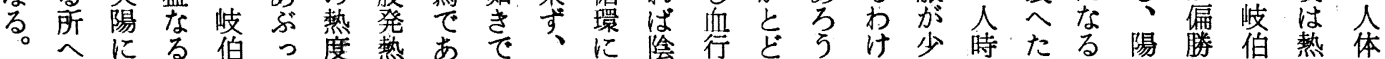

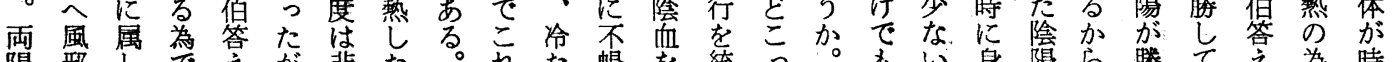

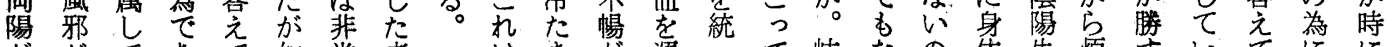
ががてあて如常者 相侵いる。尼に㤎

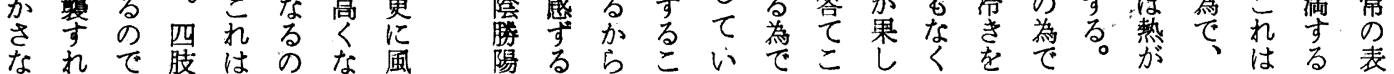

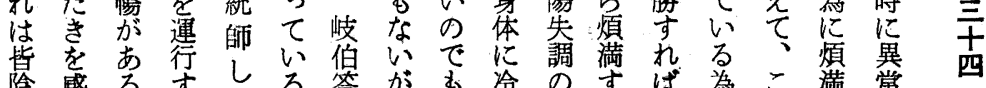

随な衰経太态蕩感で䊗で来る出しれ 腎故る相の肢芯あ。熱いしな少陰

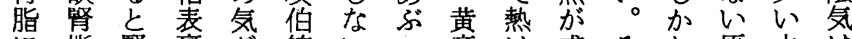

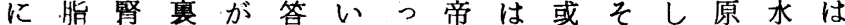

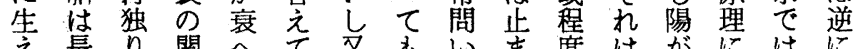

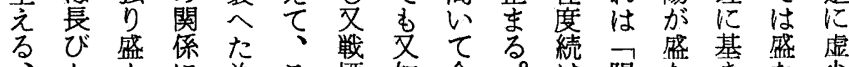

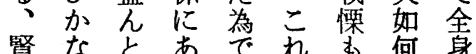
脂いなるあななた们 が。りのる紫い厚冷 骨腎孤で。水の着く

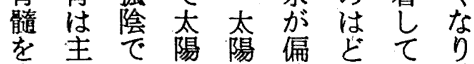

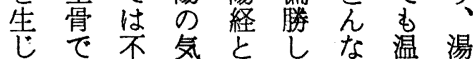

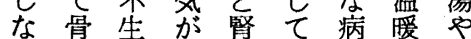

け陽なきな少

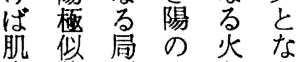
肉陰面みをっ 灼で长独減惄 熱あ 続り等水 さるき 盛 る 诮古は出な 事 不

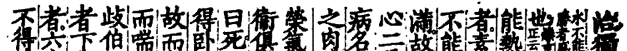

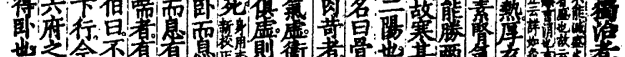

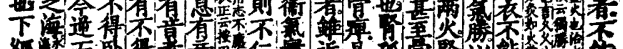

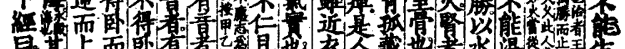

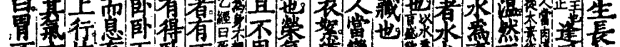

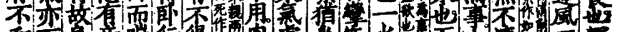

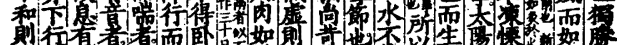

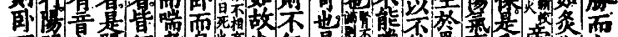

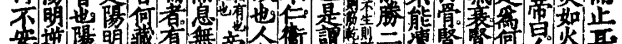

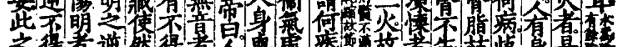

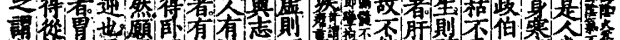

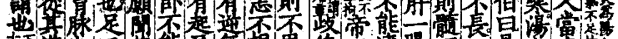

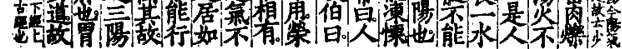


不 以衛陰ことな冷

能るは㔻れもい熱

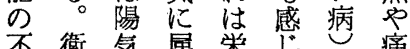

不衛気属栄岕等

用気でし衛なか餈

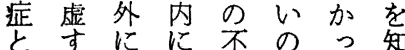

なれ運運調はたら

るば行行和ど者导

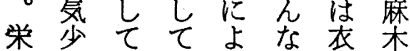

気な陰陽る病䧇服

虚くに使守す加接举

机人役とで岐し動

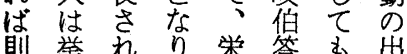

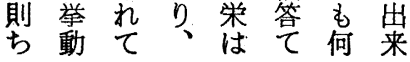

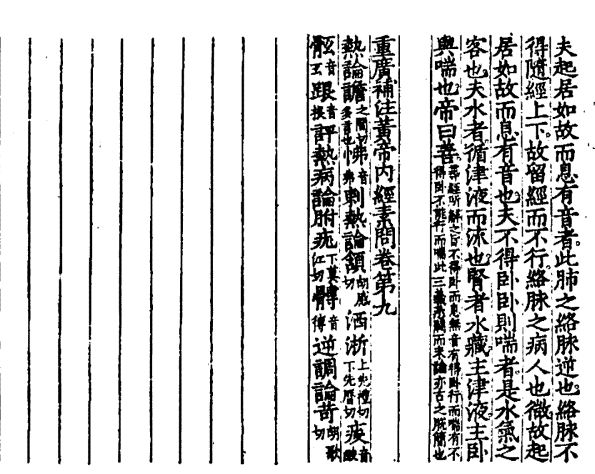

な瘦感火脂様

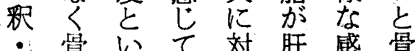

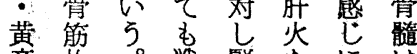

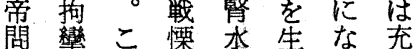

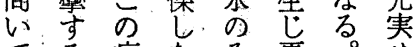
て肉病な学更東导 苛、身のは忍慄人 に寒を腾火しは 劣あてをな寒 奥感る。为吉原本 之る病にる因骨

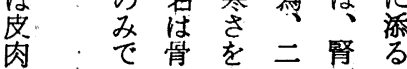

がではる行脉の音ぬしる。声現卧ずて或動れれ配き症血

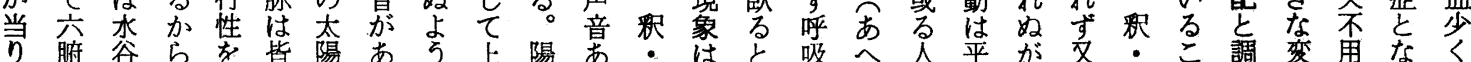

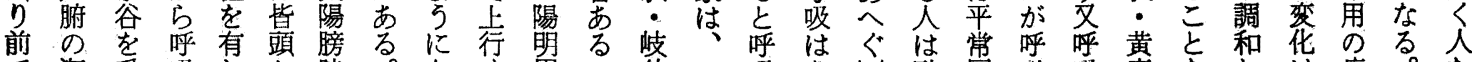

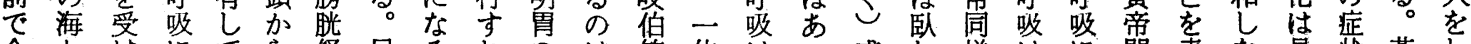

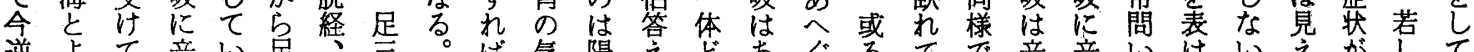

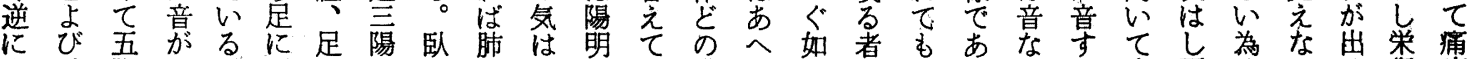

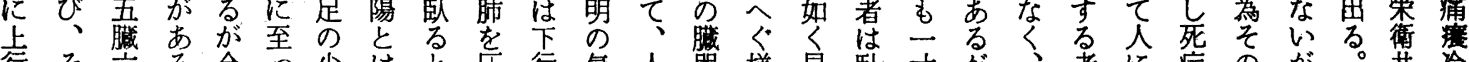

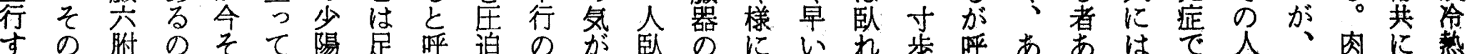

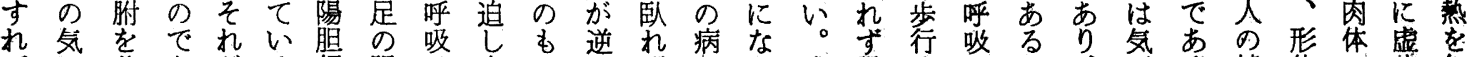

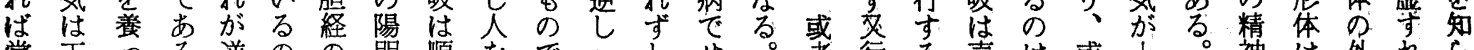
常下っる逆のの盟順をでたしせ艺著行る声は或上神は外れら

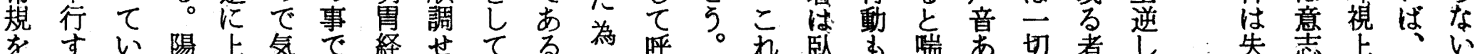
去先 る しのの胃守市足声れ逆あに: の势出息、行卧卧て支大代

る り に病 ど発 病 勝背び洗ら休皆黄 去等出、因㠿邪問 と疼、の、は傷て 熱痛寒 寒肢定つ䖒 加な槚気伯定け疾 来名驾先答特ら珼

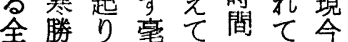

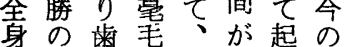
内症牙に虐ある、 外状は起疾るがラ をが音りのの病り 問出な炊発はのヤ 寒食情いとは只 が中がは原止風帝 るはて其かはにい

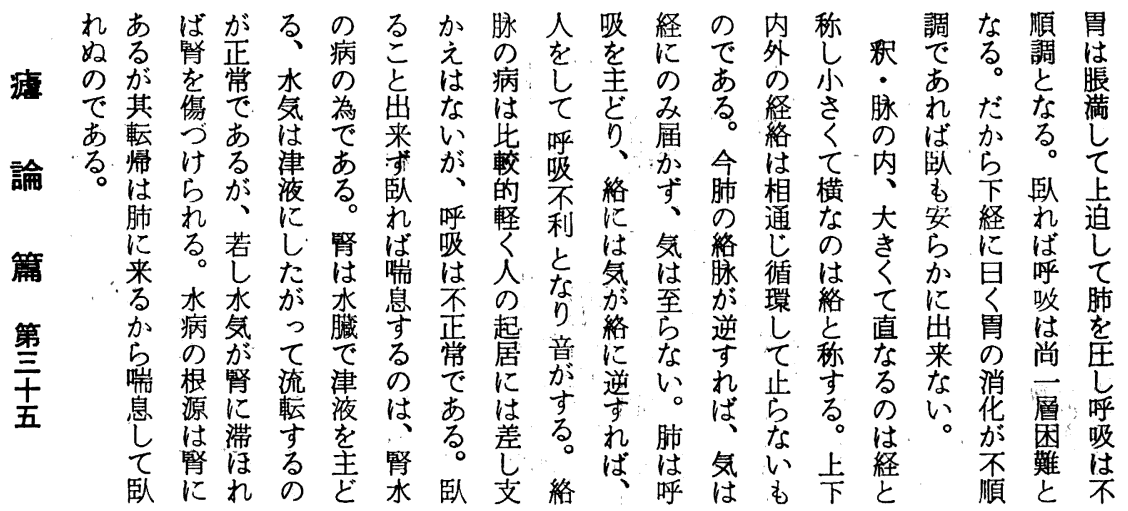

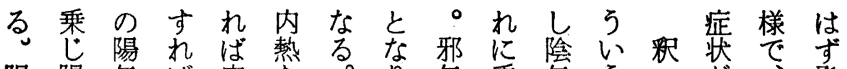

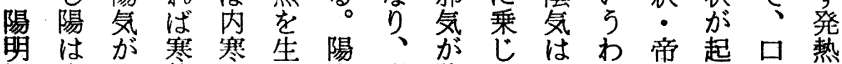

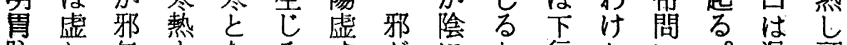

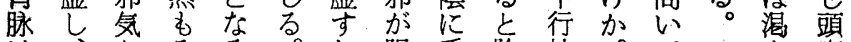

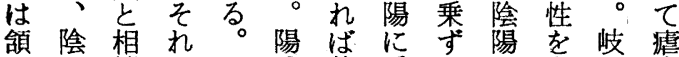

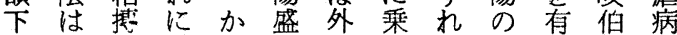
支実闘随くな寒ずば気し答に

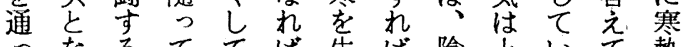

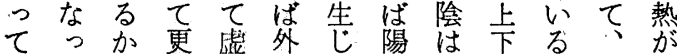
心て ら 移等陰実実交㤎陽起 る 寒邪高が歔合邪気る の寒はる相陰等陰陽孛気はの

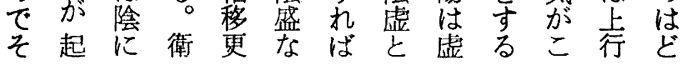

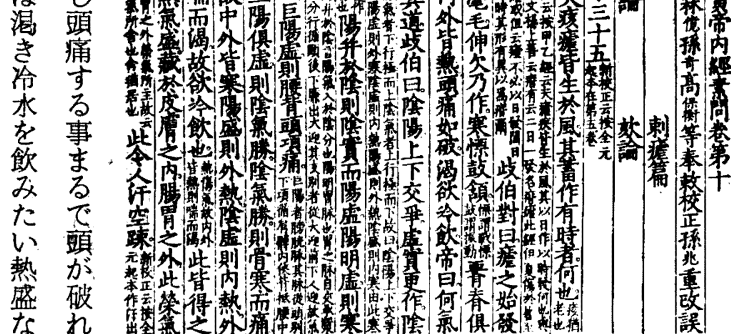




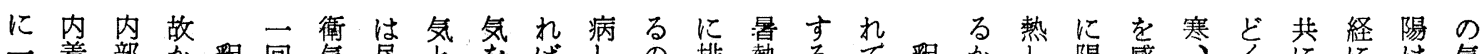

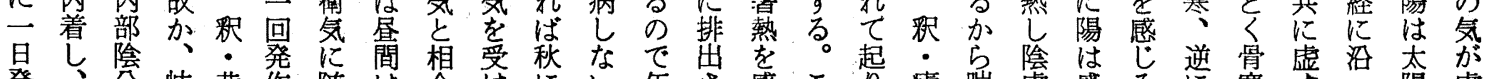

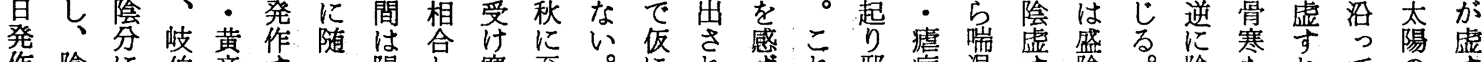

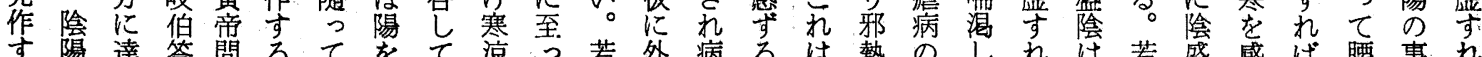
す陽達答問るて省て涼っ 若曻病るは熱のしれは若盛感ば腰事れ

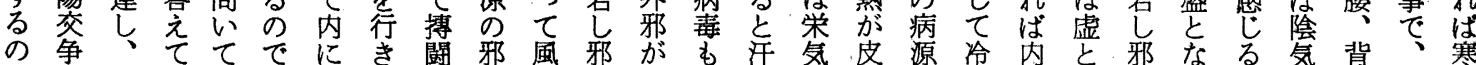

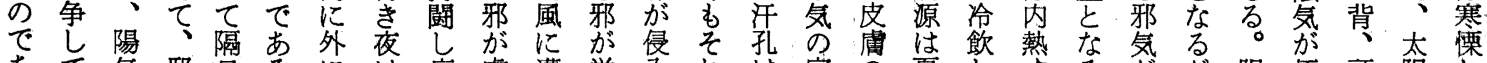

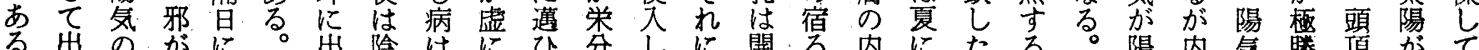
る 出 杂外夜病 為発入る

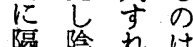

内気ば何

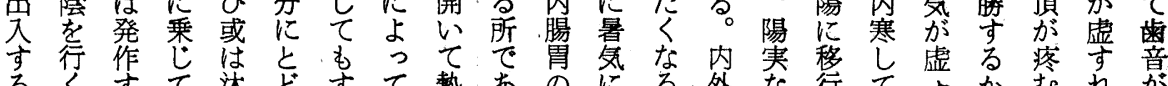

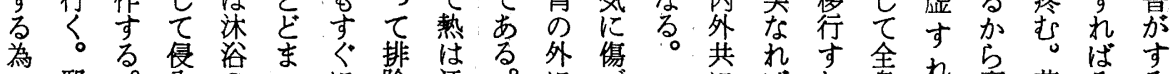

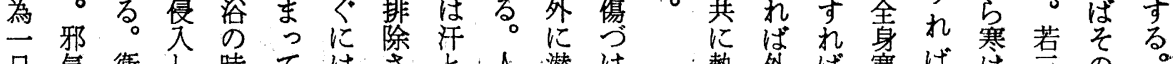

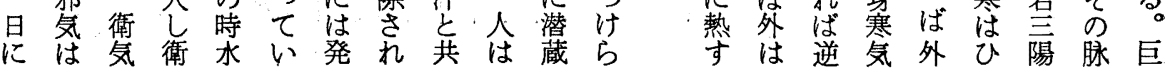

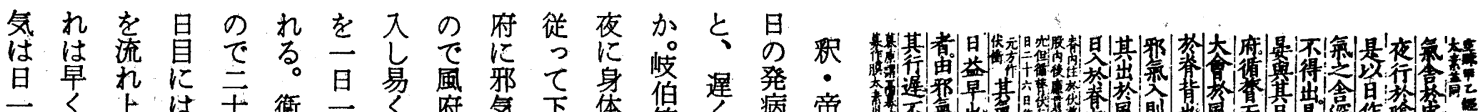

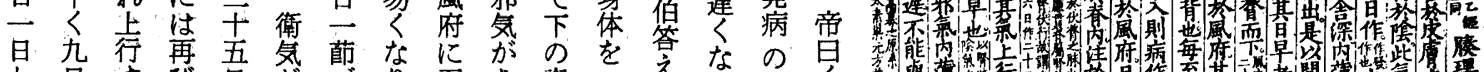

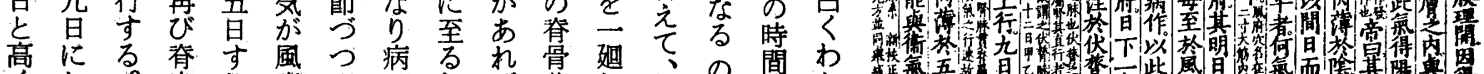

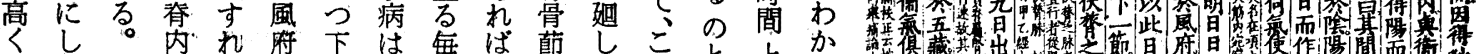

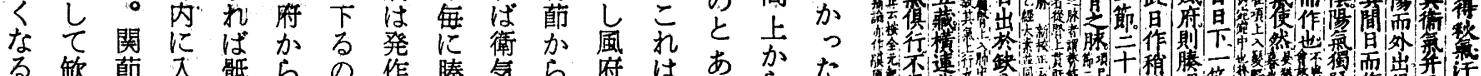
る 缼蒒 の 盆 の 阻 代

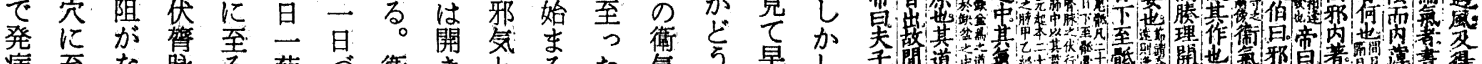

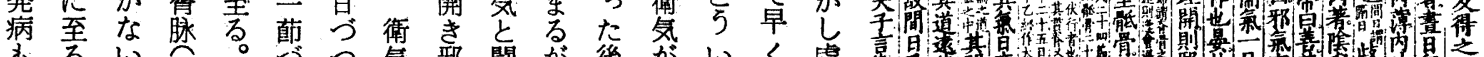
も方

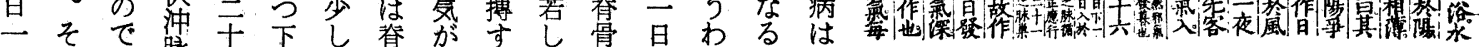

日の流永六る遅骨侵る風に具杜の毎
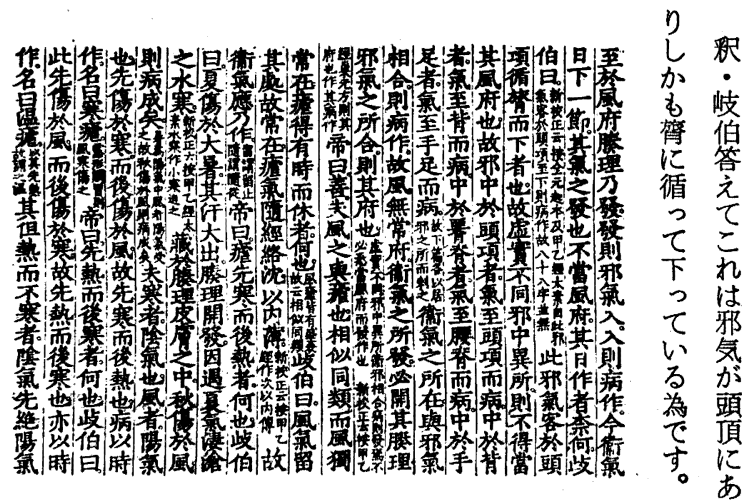

かで

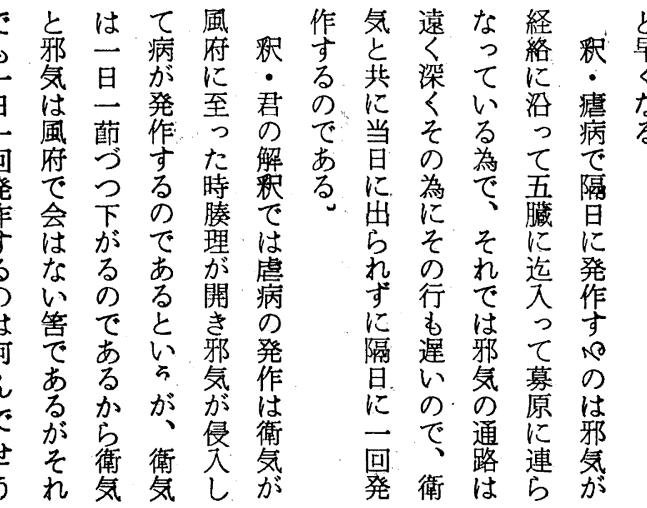

\begin{tabular}{|c|c|c|c|c|c|c|c|c|c|c|c|c|c|c|c|c|c|c|c|c|c|c|c|c|c|c|c|}
\hline & 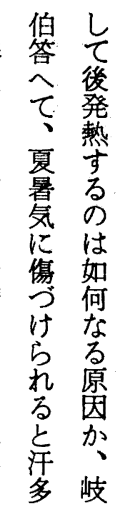 & 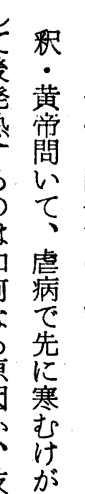 & 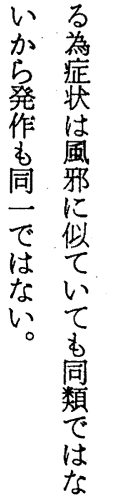 & $\begin{array}{l}\text { の } \\
\text { で } \\
\text { 発 } \\
\text { 病 } \\
\text { は } \\
\text { 衛 } \\
\text { 気 } \\
\text { 方 } \\
\text { 行 } \\
\text { き } \\
\text { 会 } \\
\text { た } \\
\text { 哲 } \\
\text { に } \\
\text { 表 } \\
\text { 机 }\end{array}$ & 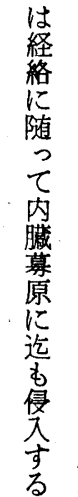 & \multicolumn{2}{|c|}{ 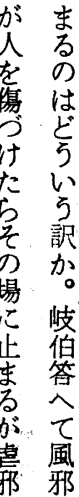 } & 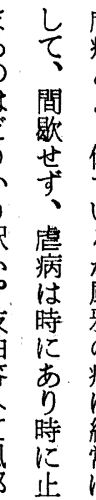 & \multicolumn{2}{|c|}{ 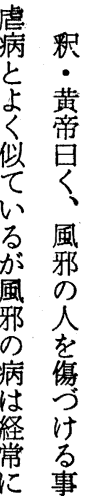 } & $\begin{array}{l}\text { か } \\
\text { ڤ } \\
\text { 発 } \\
\text { 病 } \\
\text { す } \\
\text { る } \\
\text { 哲 } \\
\text { あ } \\
\text { る }\end{array}$ & \multicolumn{2}{|c|}{ 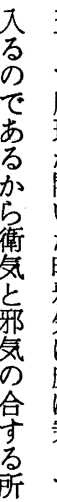 } & $\begin{array}{l}\text { 人 } \\
\text { 寸 } \\
\text { る } \\
\text { は } \\
\text { 固 } \\
\text { せ } \\
\text { 場 } \\
\text { 所 } \\
\text { く }\end{array}$ & \multicolumn{2}{|c|}{$\begin{array}{l}\tau \\
\text { 邪 } \\
\text { 気 } \\
\text { と } \\
\text { 弇 } \\
\text { 乙 }\end{array}$} & & \multicolumn{2}{|c|}{ 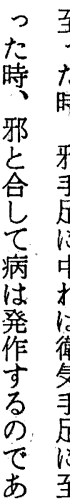 } & 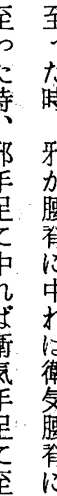 & \multicolumn{3}{|c|}{$\begin{array}{l}\text { に至 } \\
\text { た } \\
\text { 時 } \\
\text { 邪 } \\
\text { 北 } \\
\text { 背 } \\
\text { に } \\
\text { 中 } \\
\text { れ } \\
\text { ば } \\
\text { 衛 } \\
\text { 気 } \\
\text { 北 } \\
\text { 背 } \\
\text { に }\end{array}$} & & & & \\
\hline
\end{tabular}




\begin{tabular}{|c|c|c|c|c|c|c|c|c|c|c|c|c|c|c|c|c|c|c|c|c|c|c|c|c|c|c|c|c|}
\hline 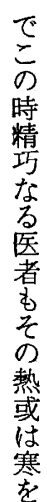 & 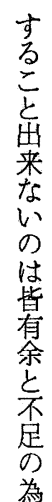 & 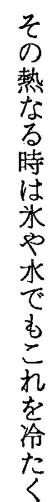 & 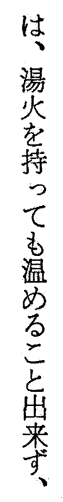 & $\begin{array}{l}\text { は } \\
\text { 有 } \\
\text { 余 } \\
\text { 寒 } \\
\text { は } \\
\text { 不 } \\
\text { 足 } \\
\text { 楕 } \\
\text { 㵙 } \\
\text { る }\end{array}$ & 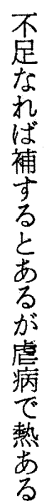 & 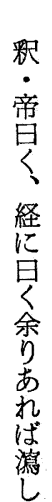 & 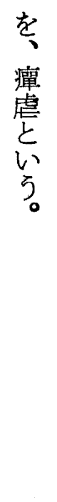 & 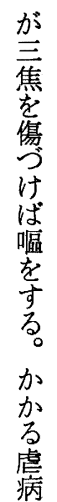 & $\begin{array}{l}\text { 本 } \\
\text { な } \\
\text { る } \\
\text { 故 } \\
\text { 陽 } \\
\text { 盛 } \\
\text { な } \\
\text { れ } \\
\text { ば } \\
\text { 手 } \\
\text { は } \\
\text { 熱 } \\
\text { 多 } \\
\text { る。 }\end{array}$ & 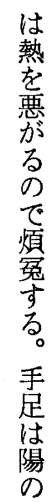 & 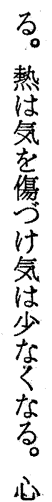 & 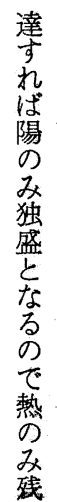 & 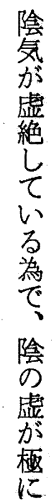 & $\begin{array}{l}\text { 虚 } \\
\text { 熱 } \\
\text { 势 } \\
\text { み } \\
\text { あ } \\
\text { ? }\end{array}$ & $\begin{array}{l}\text { 䖈 } \\
\text { 名 } \\
\text { 名 } \\
\text { け } \\
\text { る }\end{array}$ & 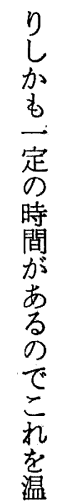 & $\begin{array}{l}\text { そ } \\
\text { の } \\
\text { 病 } \\
\text { 型 } \\
\text { 先 } \\
\text { 熱 } \\
\text { 後 } \\
\text { 後 }\end{array}$ & 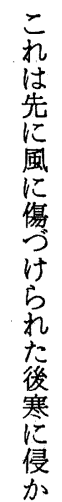 & 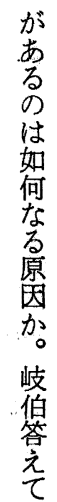 & 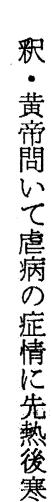 & 䖈 & & & $\begin{array}{l}\text { す } \\
\text { る } \\
\text { 先 } \\
\text { は } \\
\text { 寒 }\end{array}$ & $\begin{array}{l}\text { 抙 } \\
\text { に } \\
\text { 侵 }\end{array}$ & 邪 & & \\
\hline
\end{tabular}

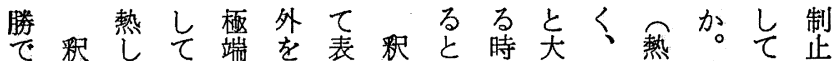

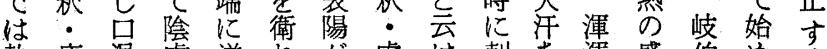

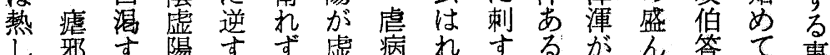

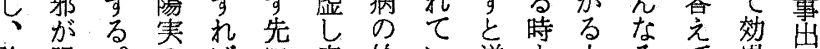
陰陽。のばに内姶い逆它大る夲果来

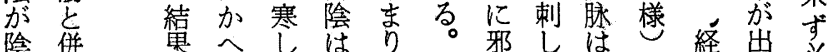

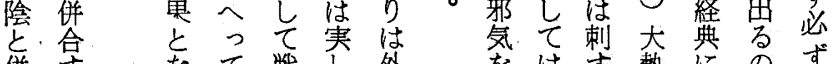
併守市て戦它外 合れり外慄元陽 すば、、外表が れ陽陽出る。陽 内 ば陰腾: 実陽陰な虚陰

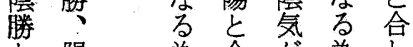
と陽 為合 加為し
をは歖に熱すず しなですに何を 否いな今゙熇な待

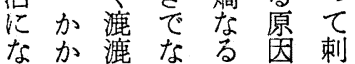

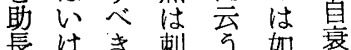

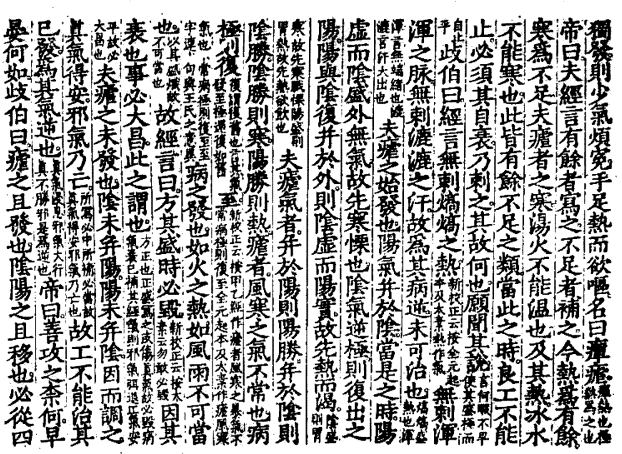

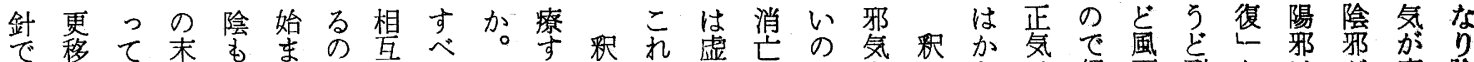

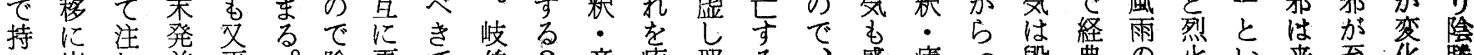

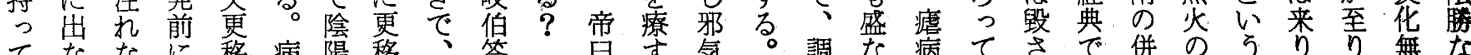

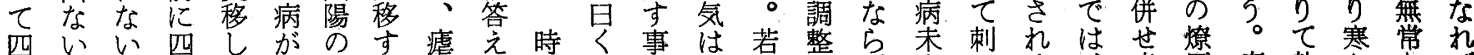

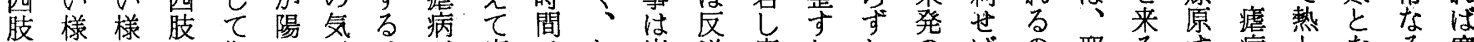

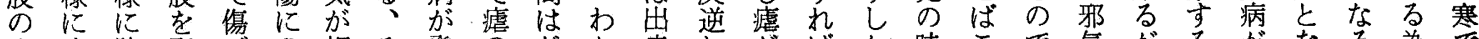

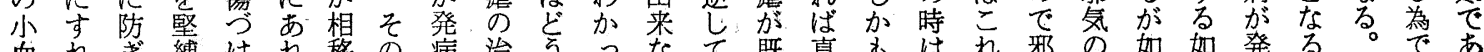

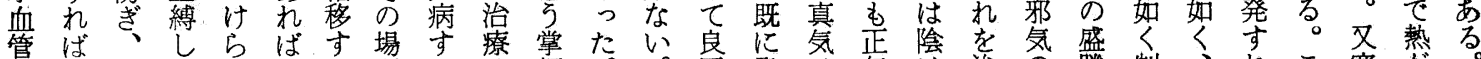

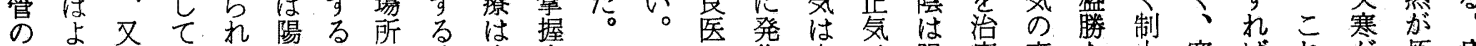

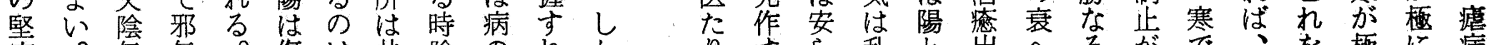

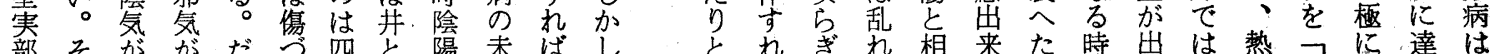

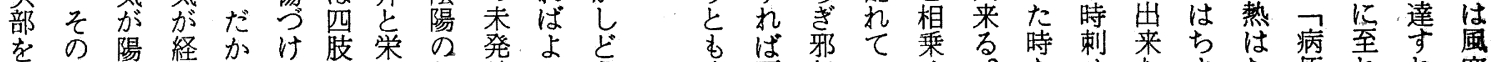

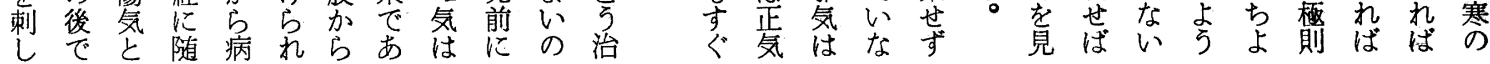

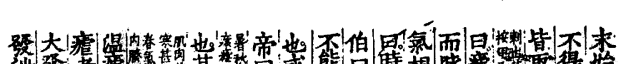

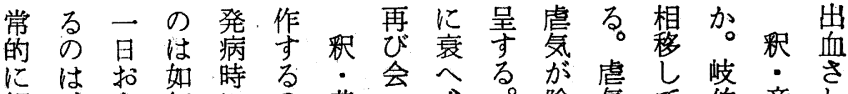

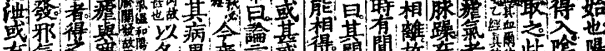

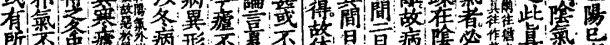

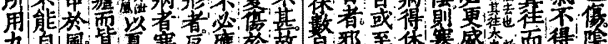

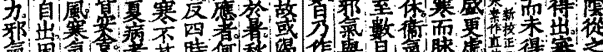

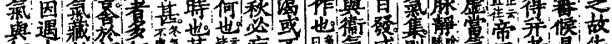

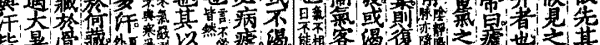

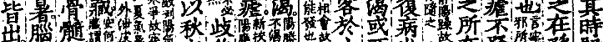

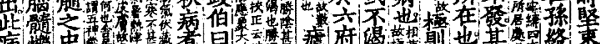

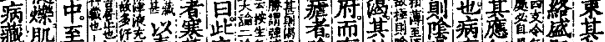

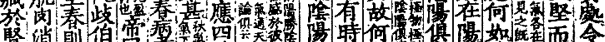

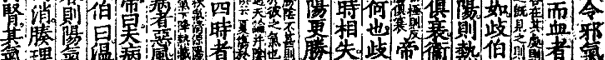

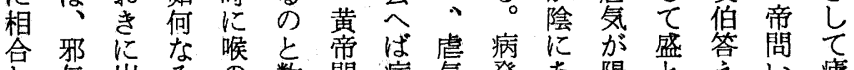

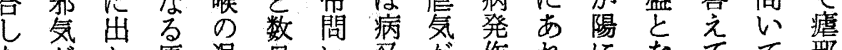

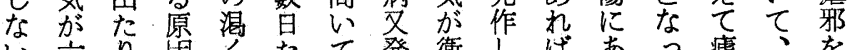

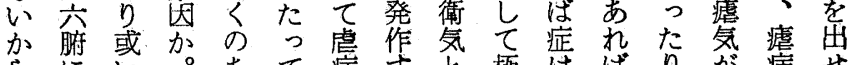

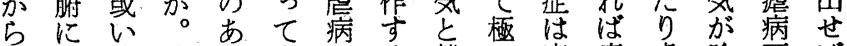

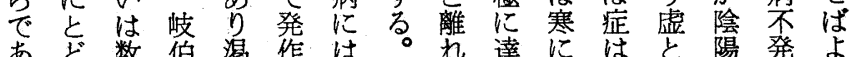

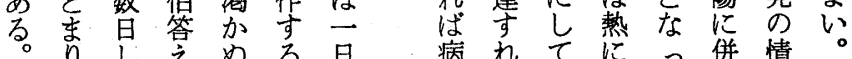
啒 衛 て が気た虔の市き く経す注るり発 病れてにっ併情 は休陰はした会沇

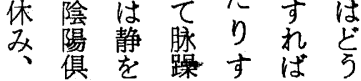




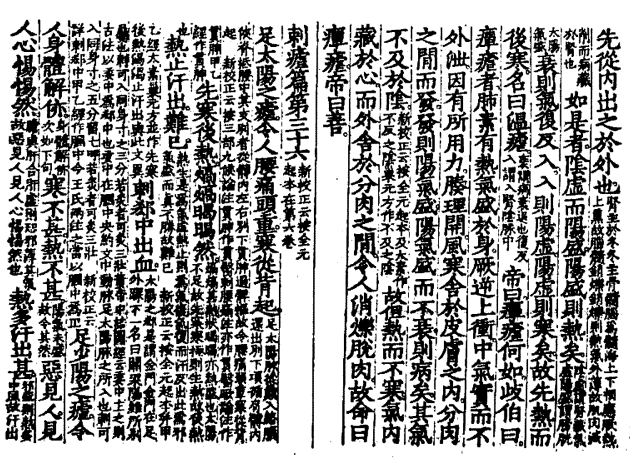

し 起気染とで虐か。時秋 いり 熱なの

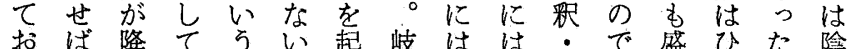
る寒可すの異导伯々必帝あ孟どり陽

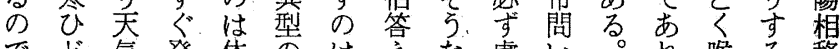

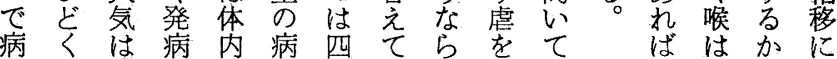

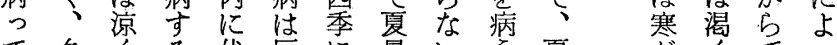

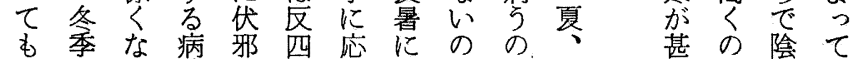

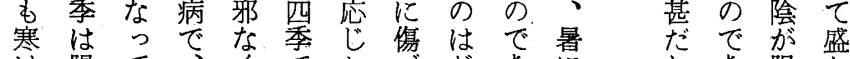

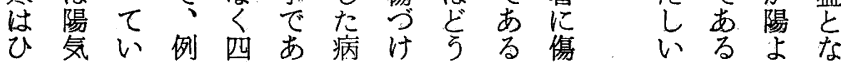

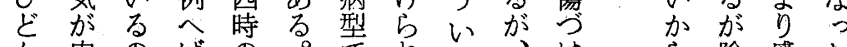

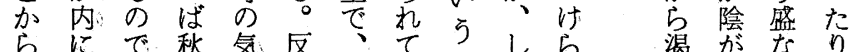

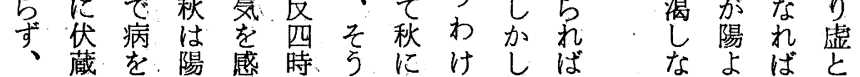

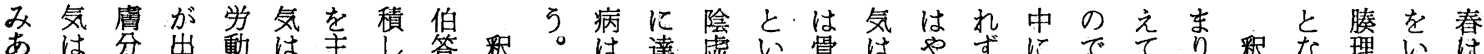

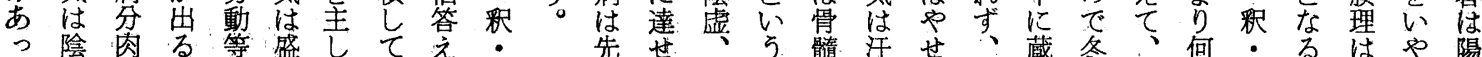

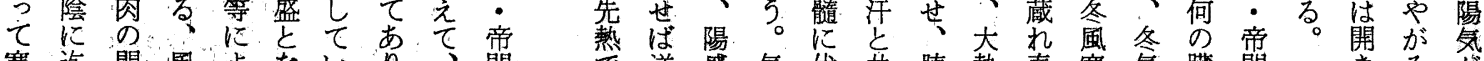

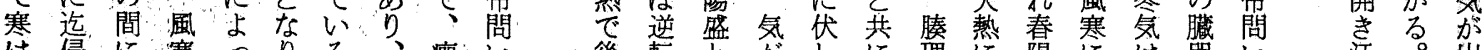

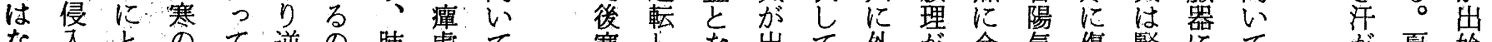

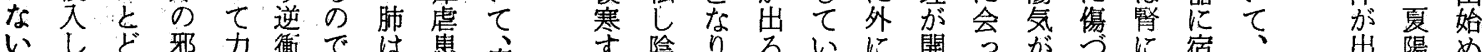

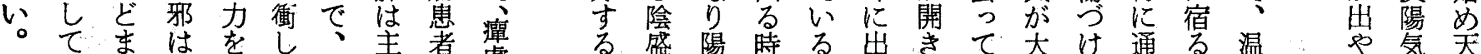
邪いつ機使てて肺、去者虔

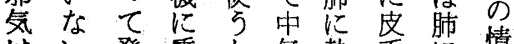

は発乗立気熱毛望情

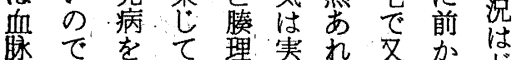

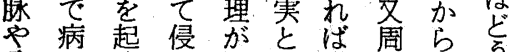

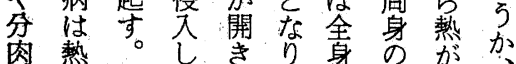
因熱邪皮汗岛射気蒀岐

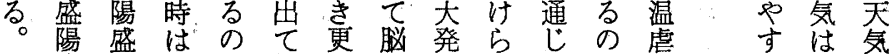

こ虚な内て解に髓寺れ、だや外は

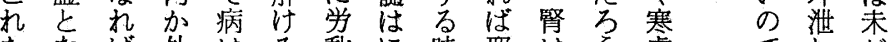

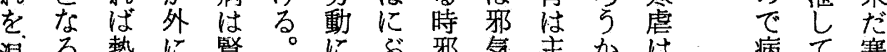

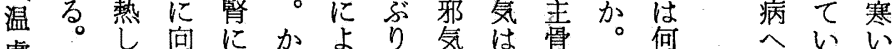

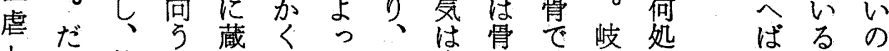

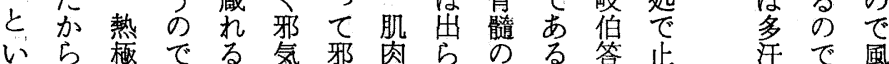

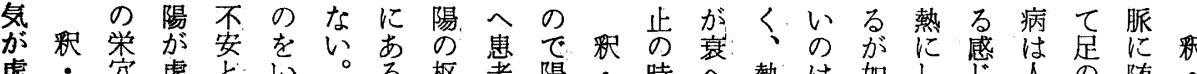

虚足穴虚 な

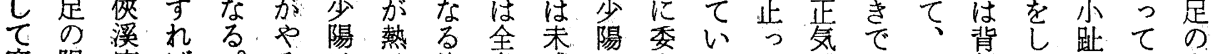

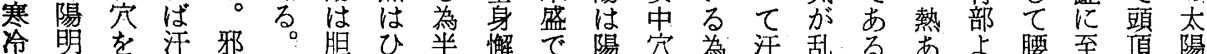

を経刺が気人経ど表意あがを㹥がれ。るる 痛っ膀

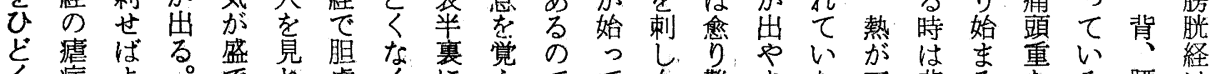

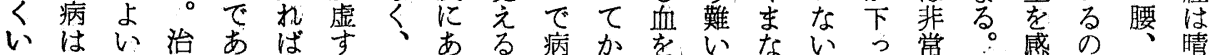

や先。療れ驚れ又る。へた症留で臂奛

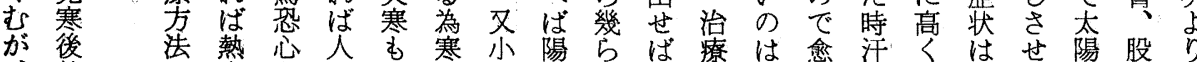

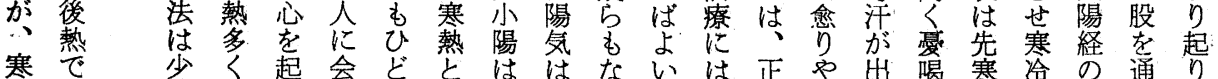

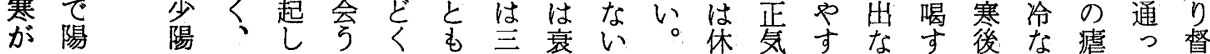

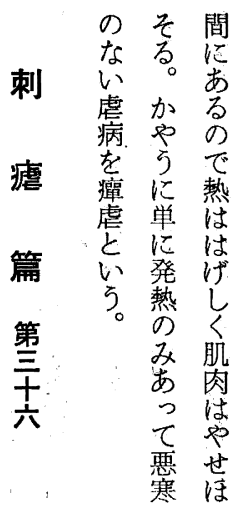

でる 発 夌為泉恢若

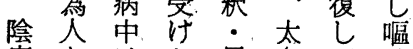

病をは足白て品

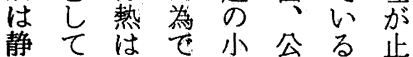

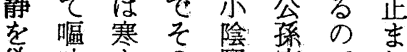

欲哆占 の 督容でれ

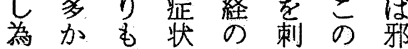

にら長は㗔世時が

閏し以寒病ばに衰

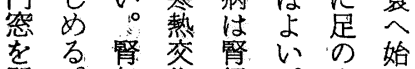

閉。気作経。太妿

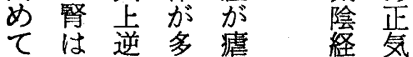

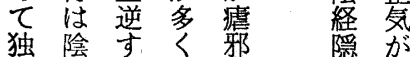

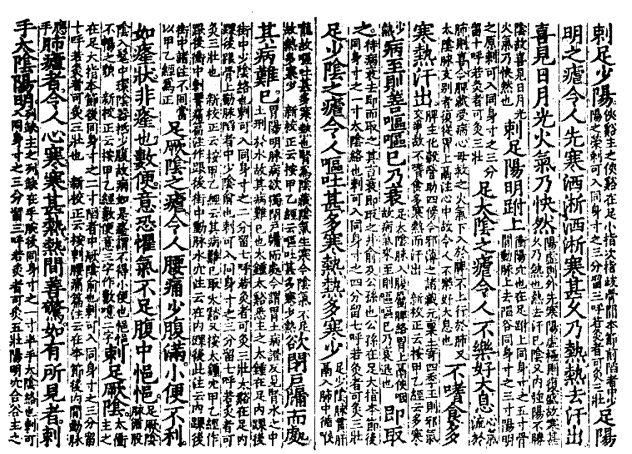

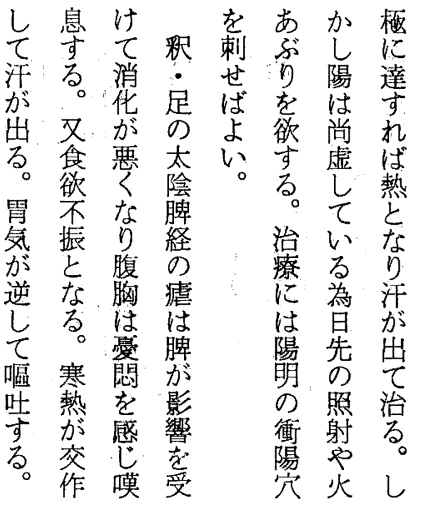


死ばすは寒れたで。列くそ起足すか度み腹け原違居

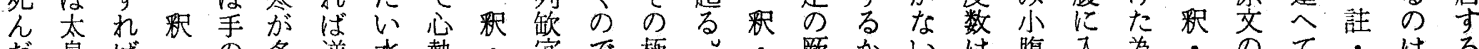

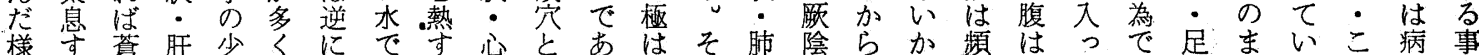

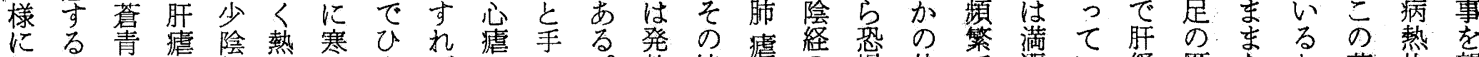

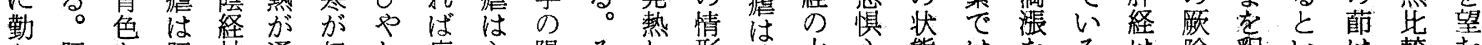

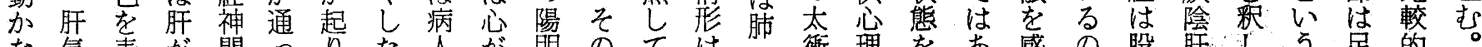

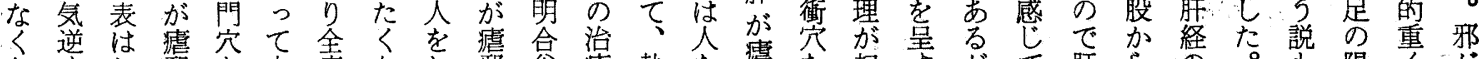

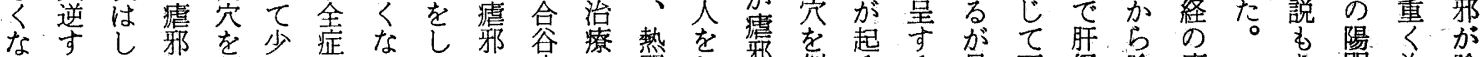

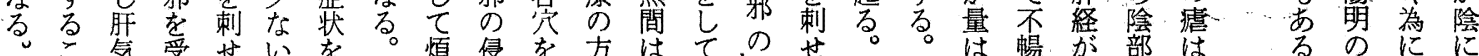

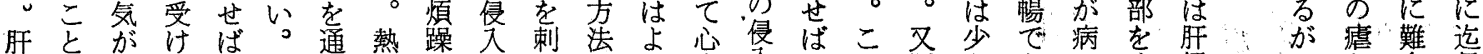

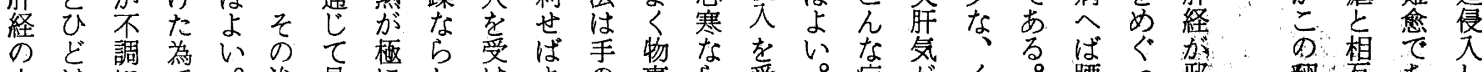
中けにで。治. 見にしけよの事ら受。症がく腰っ、邪

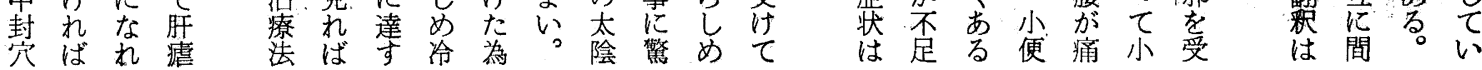

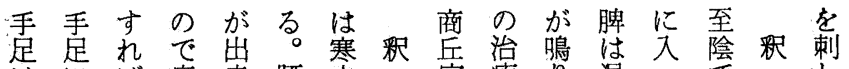

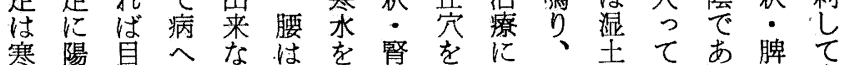
冷のがばく㻉主瘧刺は湿にいる㠊出

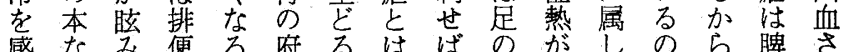

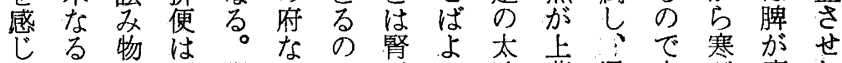

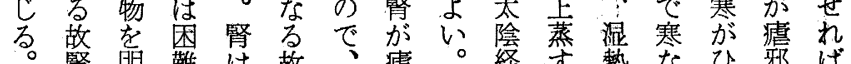

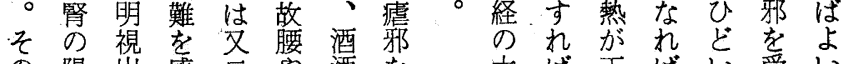

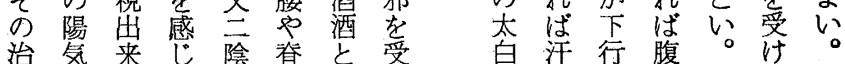

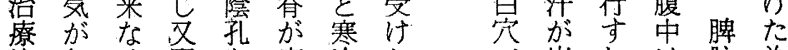

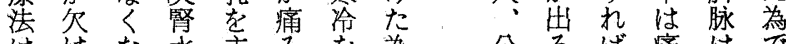

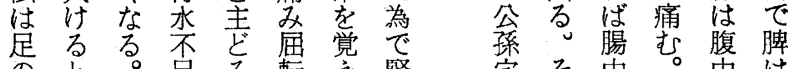

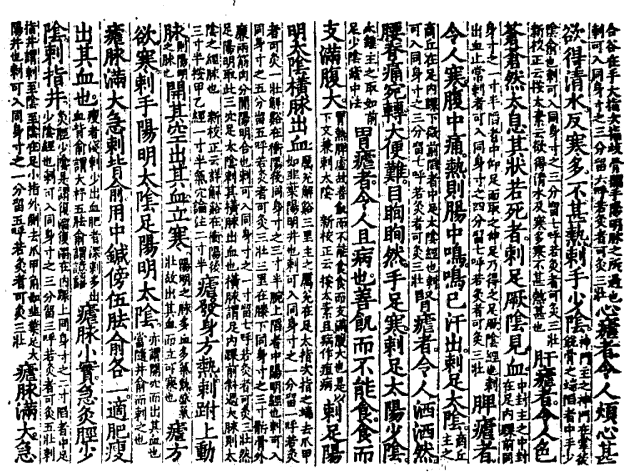

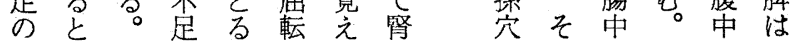

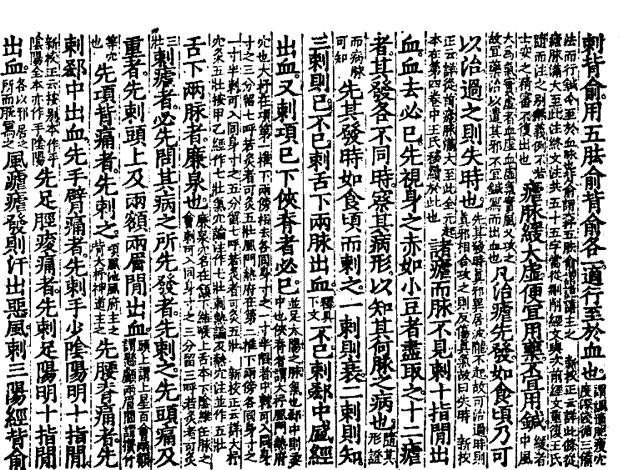

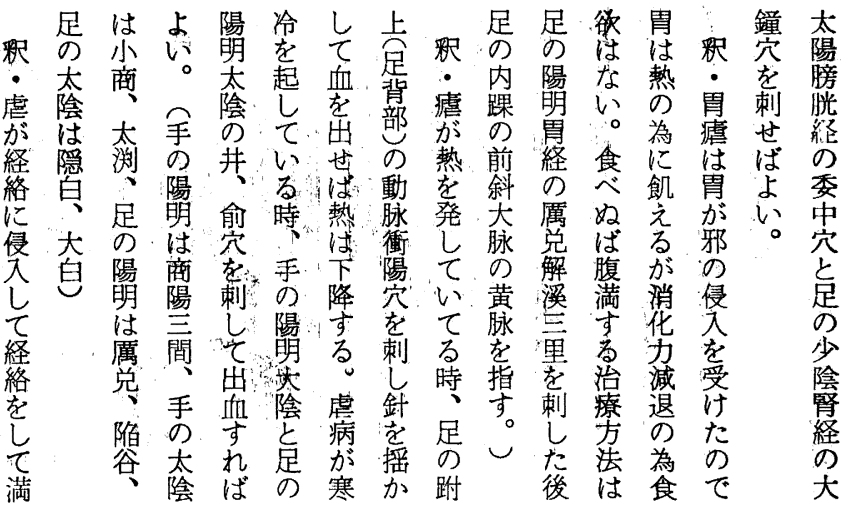

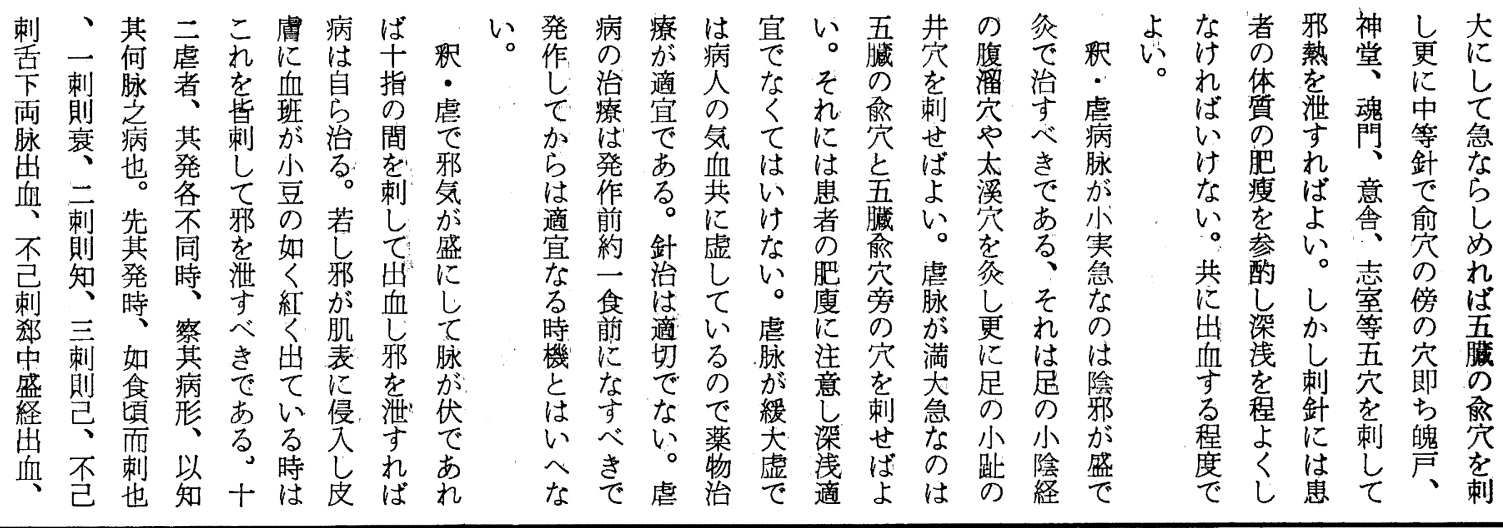




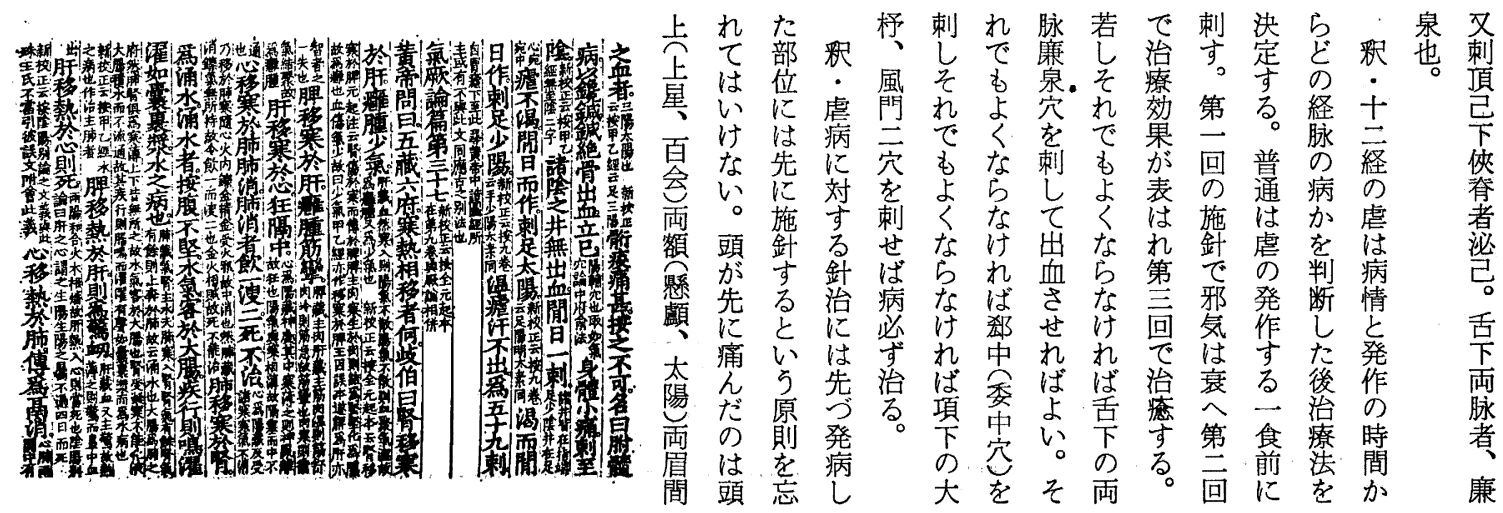

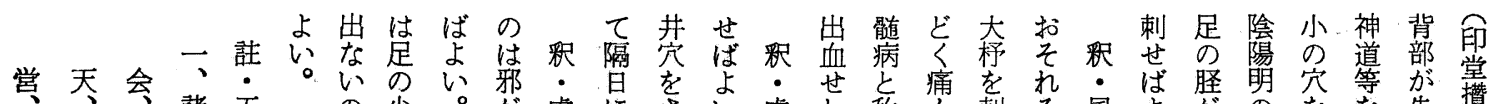

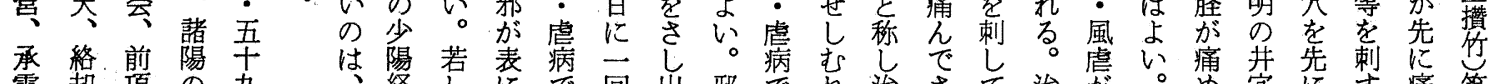

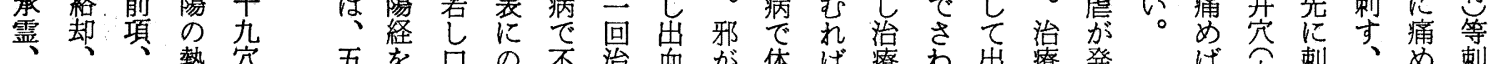

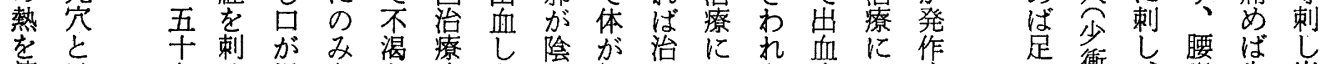

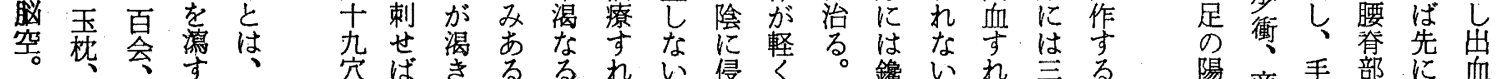

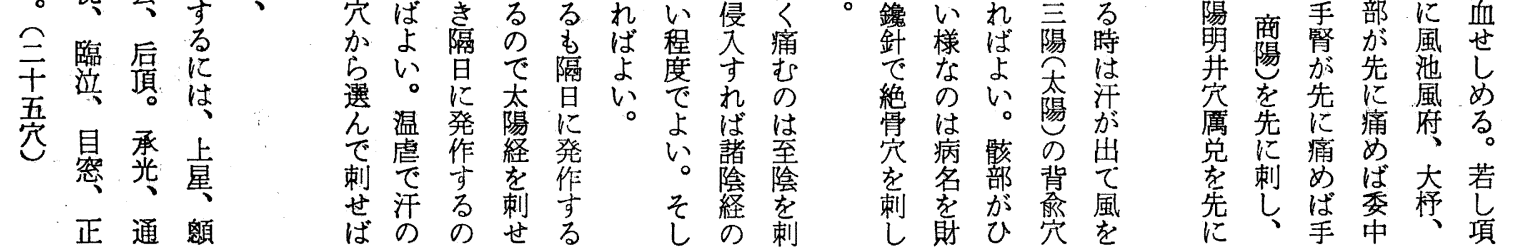
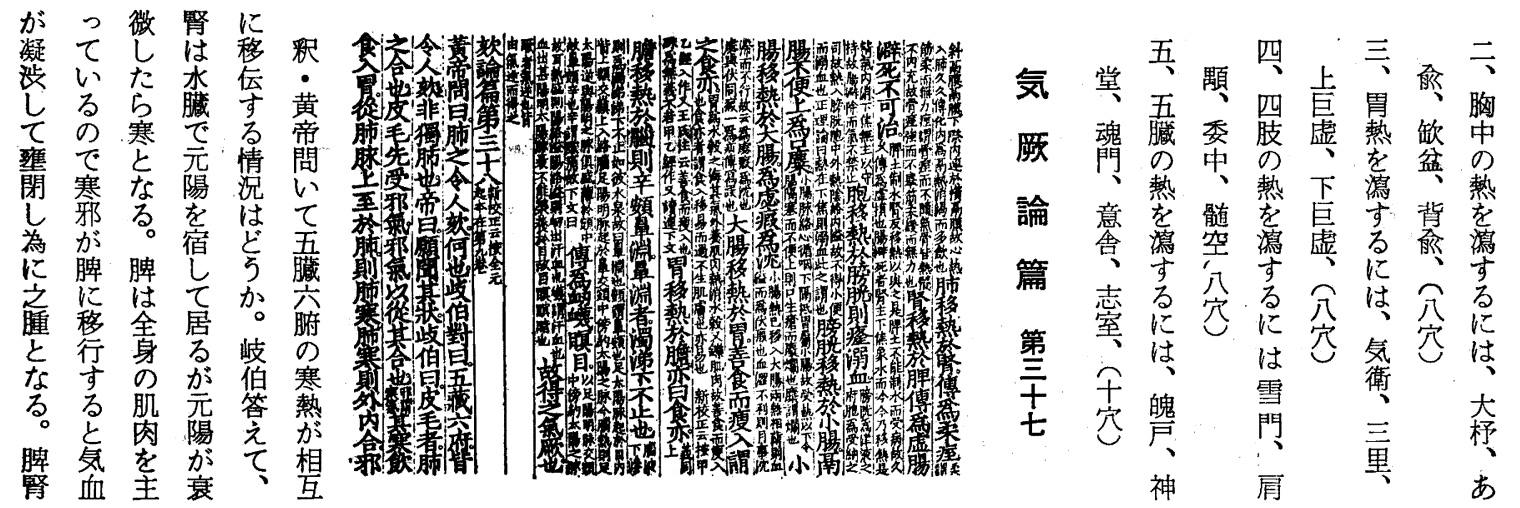

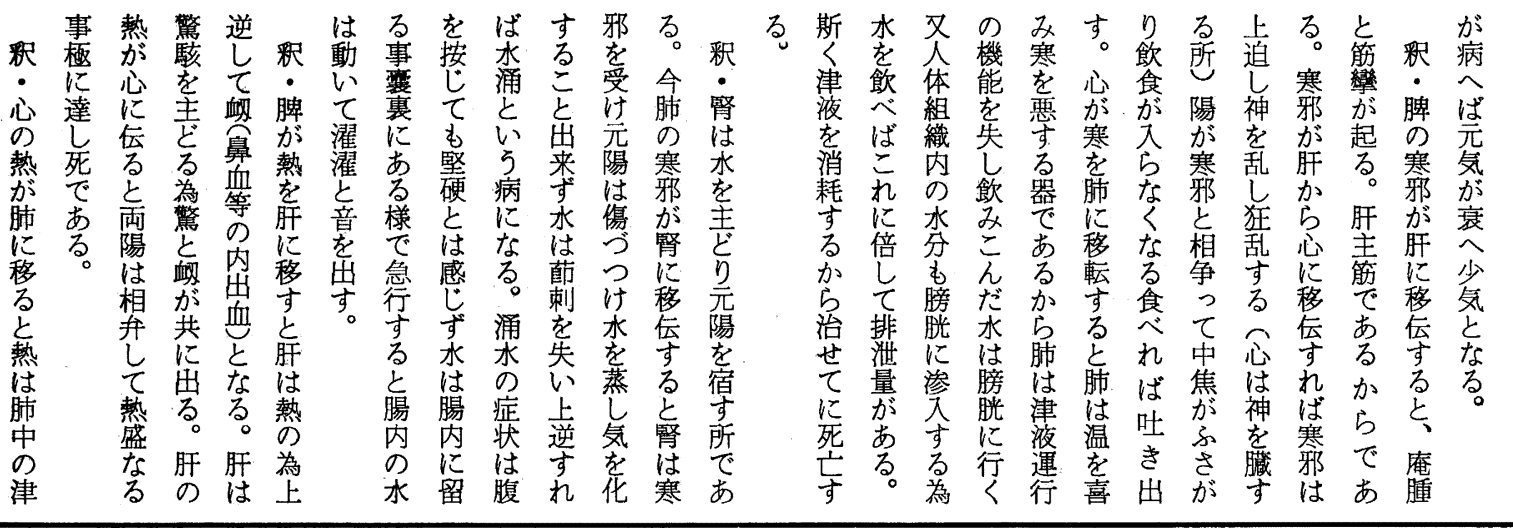




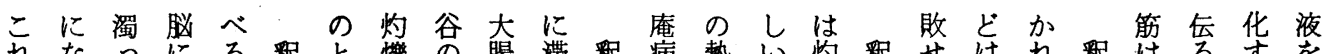

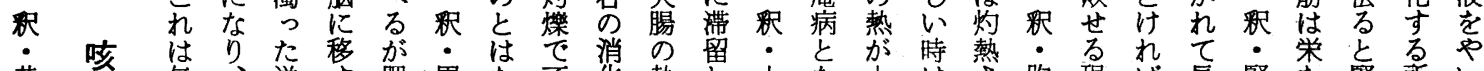

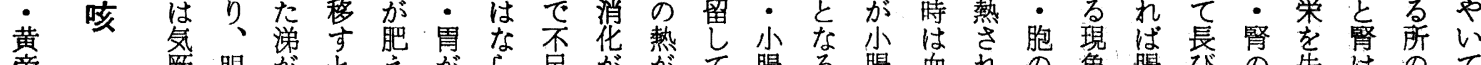

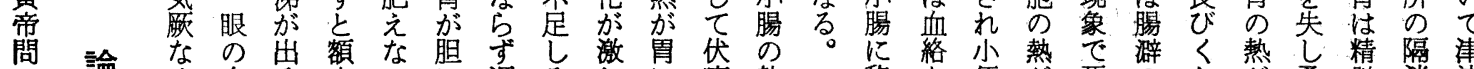
問 論 る

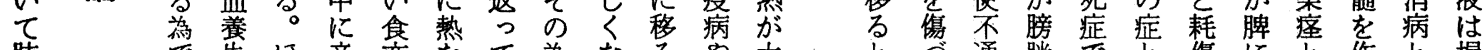

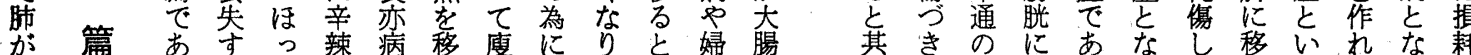

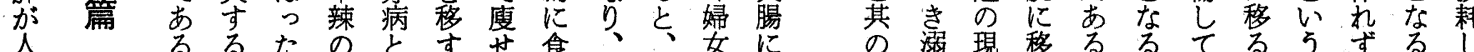
艺 第 る る

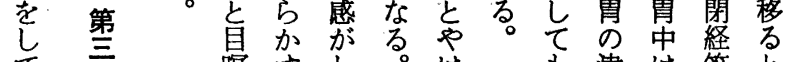

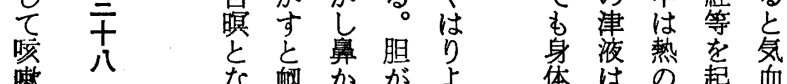

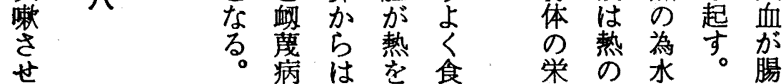
㷫 血 象

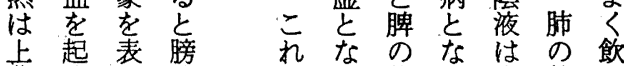
蒸すは胱水り墔る。少熱み

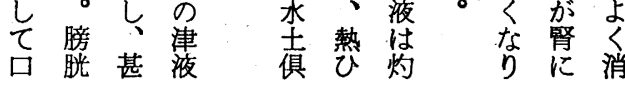

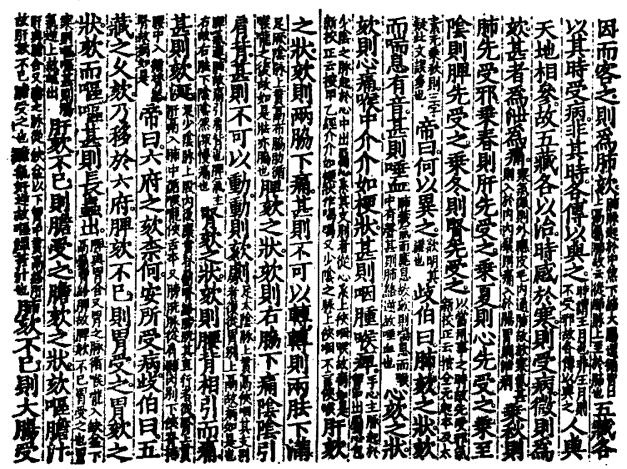

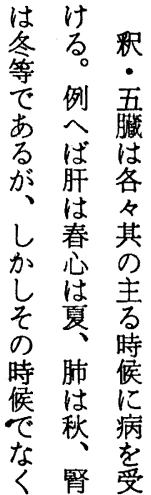

咳 来

来肺食てるる風濑

み六腑 る 世寒永㭬嗽こ皮会し。な俱は

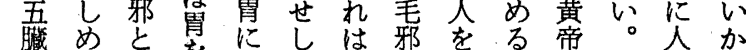

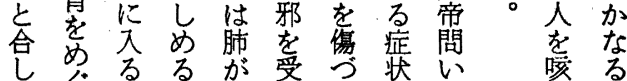
てぐる る が受方状 肺乞之界感れる知五 世思

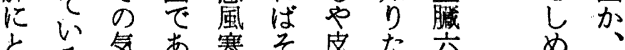

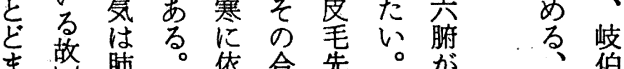
り肺脉寒っ肺分岐人単答

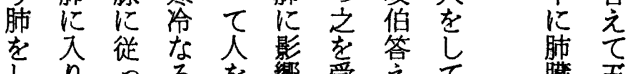

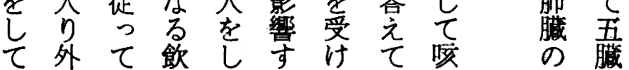

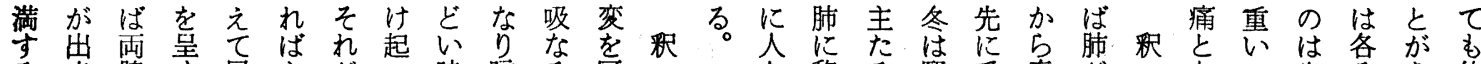

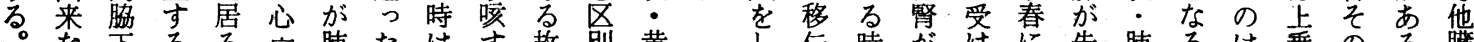

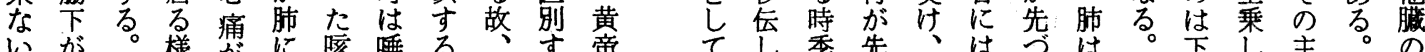

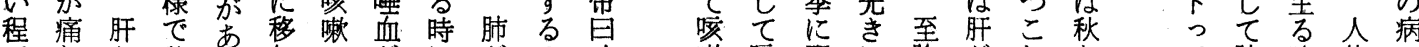

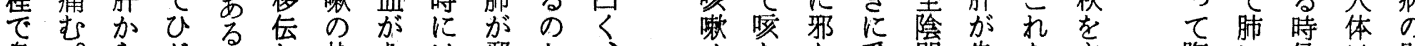
身。らど。し状あは邪か、索をを受即先を主腹に候は影 体ひ来い喉てでる喘を、どし成受讨長に受る をとるる時喉咳あ。息受岐 回い肺は喿嗽るこう意け伯い

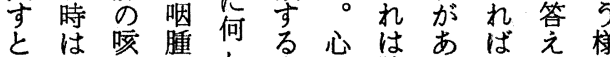

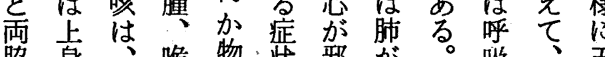

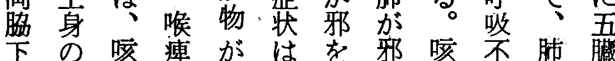
が転守のつ咳受を高利主の る いる、、蔵脾け肝に

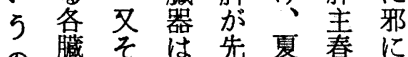
の器ら各には告佰 で 邪名受心ある 泄入㳊 之 な咳受相受

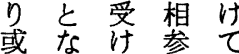
いるる合発 は、がし 病 周毞軖无吉

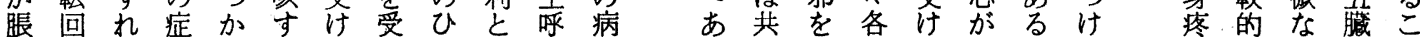

\begin{tabular}{|c|c|c|c|c|c|c|c|c|c|c|c|c|c|}
\hline 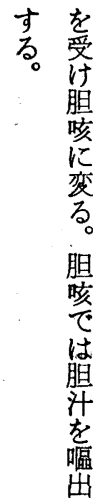 & 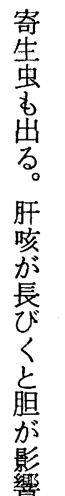 & \multicolumn{2}{|c|}{ 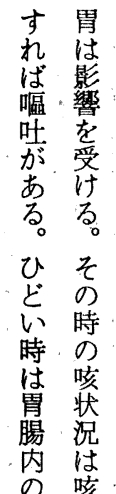 } & \multicolumn{2}{|c|}{ 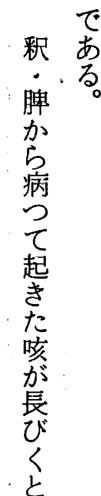 } & $\begin{array}{l}\text { 吾 } \\
\text { 藏 } \\
\text { 咳 } \\
\text { 占 } \\
\text { 長 } \\
\text { び } \\
\text { W } \\
\tau \\
\text { 治 } \\
\text { 号 } \\
\text { に } \\
\text { 移 } \\
\text { 辰 } \\
\text { た } \\
\text { 為 }\end{array}$ & \multicolumn{2}{|c|}{ 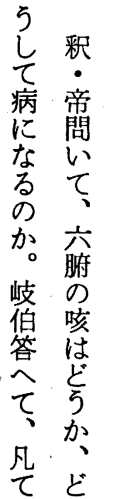 } & \multicolumn{2}{|c|}{ 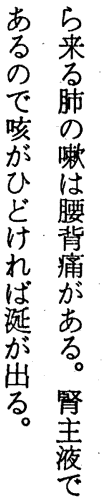 } & \multicolumn{2}{|c|}{ 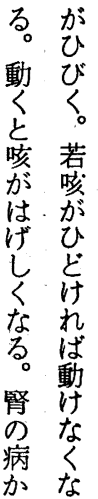 } & \\
\hline
\end{tabular}

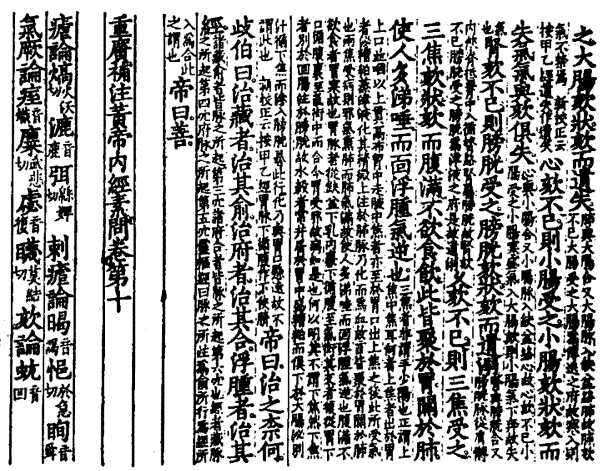

